\title{
Genetic Aspects of Myelodysplastic/Myeloproliferative Neoplasms
}

\author{
Laura Palomo ${ }^{1,2}$, Pamela Acha ${ }^{1}$ iD and Francesc Solé ${ }^{1, *} \mathbb{D}$ \\ 1 MDS Group, Institut de Recerca Contra la Leucèmia Josep Carreras, ICO-Hospital Germans Trias i Pujol, \\ Universitat Autònoma de Barcelona, 08916 Badalona, Spain; lpalomo@carrerasresearch.org (L.P.); \\ pacha@carrerasresearch.org (P.A.) \\ 2 Experimental Hematology, Vall d'Hebron Institute of Oncology (VHIO), Vall d'Hebron Barcelona Hospital \\ Campus, Universitat Autònoma de Barcelona, 08035 Barcelona, Spain \\ * Correspondence: fsole@carrerasresearch.org; Tel.: +34-93-557-2806
}

check for updates

Citation: Palomo, L.; Acha, P.; Solé, F. Genetic Aspects of Myelodysplastic/ Myeloproliferative Neoplasms. Cancers 2021, 13, 2120. https:// doi.org/10.3390/cancers13092120

Academic Editors: Luis Colomo and Xavier Calvo

Received: 26 March 2021

Accepted: 23 April 2021

Published: 27 April 2021

Publisher's Note: MDPI stays neutral with regard to jurisdictional claims in published maps and institutional affiliations.

Copyright: (C) 2021 by the authors Licensee MDPI, Basel, Switzerland. This article is an open access article distributed under the terms and conditions of the Creative Commons Attribution (CC BY) license (https:/ / creativecommons.org/licenses/by/ $4.0 /)$.
Simple Summary: Myelodysplastic/myeloproliferative neoplasms (MDS/MPN) are clonal myeloid neoplasms characterized, at the time of their presentation, by the simultaneous presence of both myelodysplastic and myeloproliferative features. In MDS/MPN, the karyotype is often normal but mutations in genes that are common across myeloid neoplasms can be detected in a high proportion of cases by targeted sequencing. In this review, we intend to summarize the main genetic findings across all MDS/MPN overlap syndromes and discuss their relevance in the management of patients.

\begin{abstract}
Myelodysplastic/myeloproliferative neoplasms (MDS/MPN) are myeloid neoplasms characterized by the presentation of overlapping features from both myelodysplastic syndromes and myeloproliferative neoplasms. Although the classification of MDS/MPN relies largely on clinical features and peripheral blood and bone marrow morphology, studies have demonstrated that a large proportion of patients $(\sim 90 \%)$ with this disease harbor somatic mutations in a group of genes that are common across myeloid neoplasms. These mutations play a role in the clinical heterogeneity of these diseases and their clinical evolution. Nevertheless, none of them is specific to MDS/MPN and current diagnostic criteria do not include molecular data. Even when such alterations can be helpful for differential diagnosis, they should not be used alone as proof of neoplasia because some of these mutations may also occur in healthy older people. Here, we intend to review the main genetic findings across all MDS/MPN overlap syndromes and discuss their relevance in the management of the patients.
\end{abstract}

Keywords: myelodysplastic/myeloproliferative neoplasms; cytogenetics; molecular landscape; gene mutations

\section{Introduction}

Myelodysplastic/myeloproliferative neoplasms (MDS/MPN) constitute a heterogeneous group of clonal myeloid malignancies with clinical, laboratory, morphologic and genetic features that overlap with myelodysplastic syndromes (MDS) and myeloproliferative neoplasms (MPN). According to the 2017 World Health Organization (WHO) classification, this category currently includes four adult subtypes: chronic myelomonocytic leukemia (CMML), BCR-ABL1-negative atypical chronic myeloid leukemia (aCML), MDS/MPN with ring sideroblasts and thrombocytosis (MDS/MPN-RS-T), MDS/MPN-unclassifiable (MDS/MPN-U), and one pediatric entity: juvenile myelomonocytic leukemia (JMML) [1].

MDS/MPN are usually characterized by a hypercellular bone marrow (BM) with increased proliferation in one or more of the myeloid lineages which is also accompanied by dysplastic features (as a result of increased programmed cell death). Simultaneously, cytopenia may also be present. The blast percentage in the BM and peripheral blood (PB) should be $<20 \%$ [1].

Depending on the subtype, conventional cytogenetics allows the identification of chromosomal abnormalities in $10-50 \%$ of the cases, while around $90 \%$ of patients present 
with somatic mutations in myeloid-related genes [2-4]. In this review, we intend to summarize the main genetic findings across all MDS/MPN overlap syndromes and discuss their relevance in the management of patients.

\section{Diagnostic Criteria of MDS/MPN}

As previously mentioned, MDS/MPN represents a heterogeneous group of myeloid malignancies that share clinicopathological features with both MDS and MPN. According to the WHO criteria, diagnosis is primarily based on morphological and laboratory findings, as well as exclusion of specific genetic abnormalities [1].

The most common and most well characterized MDS/MPN subtype is CMML, which is characterized by sustained ( $\geq 3$ months) PB monocytosis $\left(\geq 1 \times 10^{9} / \mathrm{L}\right.$; monocytes $\geq 10 \%$ ) and BM dysplasia [1]. Its incidence is estimated in four cases per 100,000 people per year [5]. Median age at diagnosis is 72 years and it is an infrequent disease in young adults [6,7]. Clinical course is highly variable, with a median overall survival (OS) that ranges between 12-24 months and 15-30\% probability of progression to acute myeloid leukemia (AML) [6]. CMML was initially considered as an MDS subtype by the French-American-British (FAB) classification, which subdivided this entity based on leukocyte count into myelodysplastic $\left(\mathrm{MD}-\mathrm{CMML},<13 \times 10^{9} / \mathrm{L}\right)$ and myeloproliferative (MP-CMML, $\geq 13 \times 10^{9} / \mathrm{L}$ ) variants [8]. In 2001, when the WHO assigned CMML to the overlap MDS/MPN group, two categories (CMML-1 and CMML-2) were distinguished according to BM or PB blast percentage [9]. In this case, the percentage of blasts represents the sum of monoblasts, promonocytes and myeloblasts. Both classifications hold prognostic value, since patients with MP-CMML or CMML-2 have shorter OS and a higher risk of AML transformation [10]. Years later, Schuler et al. proposed a refined categorization where CMML-1 subtype was divided into two groups [11]. Based on all these, current WHO classification recognizes three CMML categories: CMML-0 ( $<2 \%$ blasts in PB and $<5 \%$ blasts in BM), CMML-1 (2\% to 4\% blasts in PB and/or 5\% to 9\% blasts in BM) and CMML-2 (5\% to 19\% blasts in PB, 10\% to $19 \%$ in $\mathrm{BM}$, and/or when any Auer rods are present), but also recommends the separation of CMML into MD/MP-CMML, since this can guide the therapeutic approach [1].

Atypical CML is defined largely by morphologic criteria including leukocytosis, dysplastic neutrophils and their precursors. Cytogenetic and molecular studies should be negative for Philadelphia chromosome and $B C R-A B L$ fusion gene [1]. The exact incidence of aCML is unknown, but it is estimated in $<2$ cases for every 100 cases of BCR-ABL1positive CML [12]. Overall, aCML is generally associated with a very poor prognosis and a median OS of 10-20 months [4,13,14].

MDS/MPN-RS-T was a provisional entity until the 2017 WHO classification update, and it is characterized by the presence of thrombocytosis $\left(\geq 450 \times 10^{9} / \mathrm{L}\right)$, large atypical megakaryocytes, anemia and ring sideroblasts accounting for $\geq 15 \%$ of erythroblasts [1]. SF3B1 mutation is reported in $\sim 90 \%$ of patients [15]. In contrast to MDS-RS, the diagnosis of MDS/MPN-RS-T cannot be established if SF3B1 mutation is accompanied by $5-<15 \%$ ring sideroblasts. It represents the subtype associated with the best prognosis among overlap syndromes, with a median OS of around 6 years [16].

MDS/MPN-U is the most heterogeneous and the least well-characterized entity, including patients that do not meet other MDS/MPN diagnostic criteria. Median OS is reported in 15-25 months and leukemia-free survival in 19 months [17-19]. Clinical characteristics and the natural history of patients with MDS/MPN-U are not well established, due to the heterogeneity of the patients, although poor prognosis among patients with MDS/MPN-U is reported in several studies $[17,18,20]$.

Finally, JMML, the childhood counterpart of CMML, is a rare heterogeneous myeloid neoplasm that shares many clinical and molecular aspects of CMML, and is currently considered a bona fide RASopathy syndrome. It is the only pediatric-onset neoplasm within MDS/MPN and is characterized by excessive proliferation of granulocytic and monocytic lineages [21]. Age at diagnosis ranges from 1 month to early adolescence, but $75 \%$ of cases occur in children aged $<3$ years $[1,21]$. Splenomegaly is present almost in all 
cases. The clinical course varies widely, thus, appropriate clinical management ranges from watchful observation to early allogenic hematopoietic stem cell transplantation (HSCT) [22]

\section{Cytogenetic Abnormalities in MDS/MPN}

In general, cytogenetic abnormalities and somatic copy number alterations (CNAs) are uncommon and unspecific across all MDS/MPN subtypes (Table 1, Figure 1A), considering that the same alterations are also found in other myeloid malignancies. In most cases, prognosis is not well defined for specific alterations.

Table 1. Cytogenetic abnormalities in MDS/MPN.

\begin{tabular}{|c|c|c|}
\hline MDS/MPN & Abnormal Karyotypes (\%) & Common Abnormalities (Frequency \%) \\
\hline CMML & $30 \%$ & $\begin{array}{c}+8: 6-7 \% \\
-Y: 4-6 \% \\
-7 / \operatorname{del}(7 \mathrm{q}): 2-9 \% \\
+21: 1-2 \% \\
\text { CK: } 3-6 \% \\
\text { Deletions of } 20 \mathrm{q}(1-2 \%) \text { and } 12 \mathrm{p}(1 \%)\end{array}$ \\
\hline aCML & $43 \%$ & $\begin{array}{c}+8: 17 \% \\
-7 / \operatorname{del}(7 q): 6-8 \% \\
\text { CK: } 4-8 \%\end{array}$ \\
\hline MDS/MPN-RS-T & $10-17 \%$ & $\begin{array}{c}+8: 4 \% \\
-Y: 4 \% \\
\text { CK: } 0-4 \%\end{array}$ \\
\hline MDS/MPN-U & $50 \%$ & $\begin{array}{c}+8: 14-25 \% \\
-7 / \operatorname{del}(7 \mathrm{q}): 11 \% \\
\text { CK: } 12 \%\end{array}$ \\
\hline JMML & $19-35 \%$ & $\begin{array}{c}-7: 9-25 \% \\
\text { Others (del }(7 q),+8): 10 \%\end{array}$ \\
\hline
\end{tabular}

Abbreviations: aCML: atypical chronic myeloid leukemia; CMML: chronic myelomonocytic leukemia; CK: complex karyotype; JMML: juvenile myelomonocytic leukemia; MDS: myelodysplastic syndrome; MPN: myeloproliferative neoplasm; MDS/MPN-RS-T: myelodysplastic/myeloproliferative neoplasm with ring sideroblasts and thrombocytosis; MDS/MPN-U: myelodysplastic/myeloproliferative neoplasm unclassifiable.

The majority of CMML patients have a normal karyotype; however, around 25-30\% present with clonal cytogenetic abnormalities. Common alterations include trisomy $8(+8)$, loss of Y chromosome $(-\mathrm{Y})$, abnormalities of chromosome 7 (chr7), trisomy $21(+21)$ and complex karyotypes ( $\geq 3$ cytogenetic abnormalities; CK) [23]. Trisomy 8 is commonly found in isolation and is detected in 6-7\% of CMML patients [23,24]. Chr7 abnormalities, which mainly constitute monosomy $7(-7)$ and $7 q$ deletion $(\operatorname{del}(7 q))$, are reported in $2-9 \%$ of CMML cases $[23,24]$. These abnormalities are also present at different frequencies in other myeloid neoplasms such as MDS, MPN and AML. Finally, $-\mathrm{Y}$ is reported in $4-6 \%$ of CMML patients [23-25], although its impact is a matter of debate because, even when it has been described in several neoplasms, it is also found in healthy elderly men [28,29]. To date, three different CMML-specific cytogenetic risk classification systems have been proposed, which stratify patients in groups that differ in their OS and risk of AML progression [23-25] (Table 2). According to these, normal karyotypes and isolated $-\mathrm{Y}$ are associated with favorable outcomes. In contrast, chr7 abnormalities, CK and monosomal karyotypes (defined by the presence of two monosomies or one monosomy $+\geq 1$ structural abnormality) are associated with a poor outcome, while the prognostic impact of +8 remains controversial.

In the case of aCML, few patient cohorts with cytogenetic data have been described until now $[3,4,13,24]$, with the largest series consisting of 65 and 71 patients, respectively $[4,24]$. According to these two studies, approximately $43 \%$ of patients present with cytogenetic abnormalities, +8 and chr7 alterations being the most common, with reported frequencies of approximately $17 \%$ and $7 \%$, respectively. CK are seen in $4-8 \%$ of the cases. In contrast, only $10-17 \%$ of MDS/MPN-RS-T patients have an abnormal karyotype. Commonly de- 
tected alterations include +8 and $-\mathrm{Y}$, while other chromosomal abnormalities, as well as $\mathrm{CK}$, are rare $(0-4 \%)[4,15,26]$. Among all MDS/MPN overlap syndromes, MDS/MPN-U is the subtype with the highest frequency of chromosome instability, with near $50 \%$ of altered karyotypes. Trisomy 8 (mostly found as a sole abnormality) is the most frequent alteration (15-25\%), followed by chr7 alterations $(12 \%)$ and CK $(12 \%)[4,20,27]$. Other less common abnormalities include $\operatorname{del}(12 p),+9$ and $\operatorname{del}(20 q)[20,27]$. Overall, the presence of cytogenetic abnormalities is generally associated with an inferior OS in all adult MDS/MPN subtypes, except aCML [4]. This impact seems to be especially strong in MDS/MPN-RS-T, where abnormal karyotypes are rare but, if detected, confer a very poor outcome [4,26] (Table 2).

A

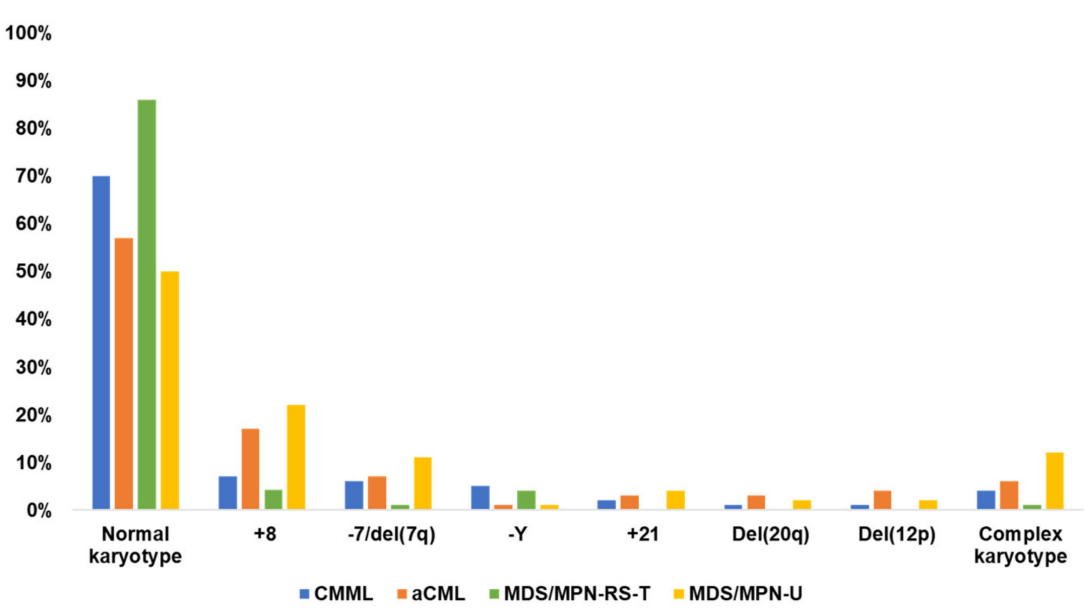

B

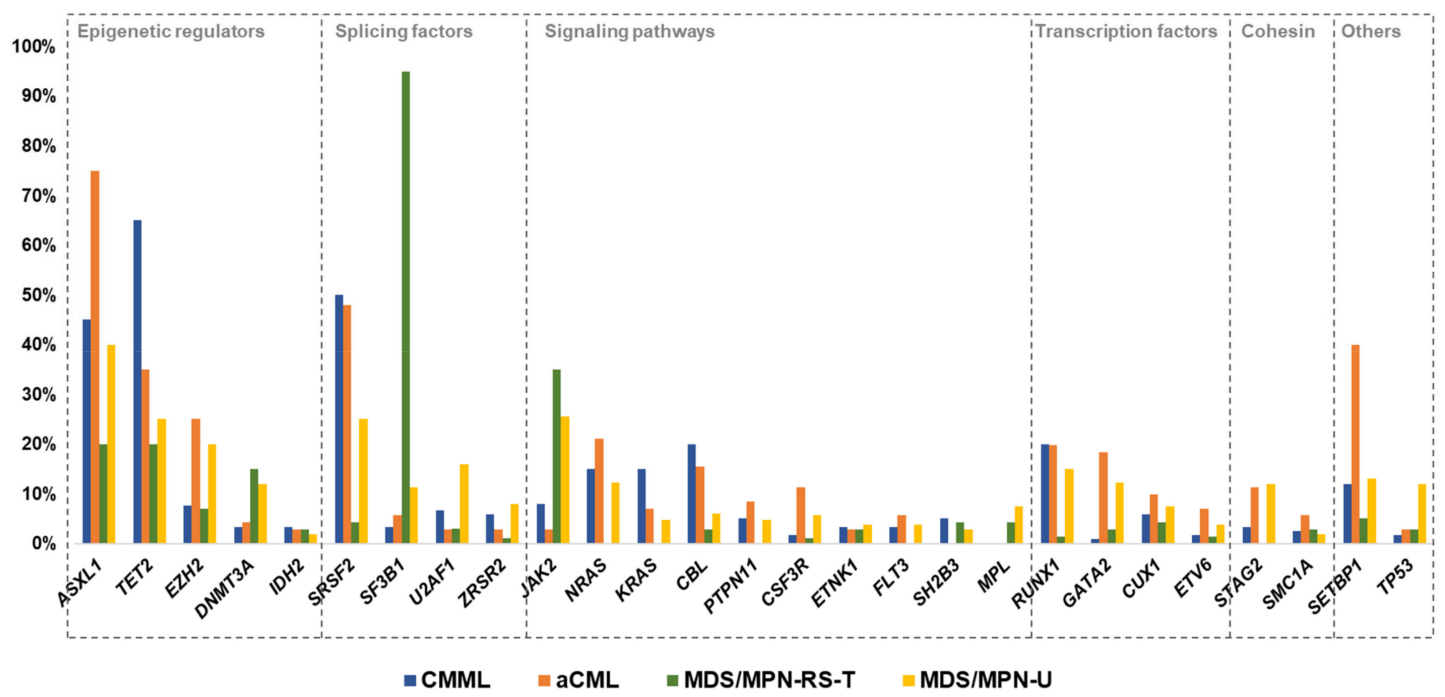

Figure 1. Genetic landscape of adult MDS/MPN. Frequency of recurrent cytogenetic alterations (A) and gene mutations (B) across the different subtypes of adult MDS/MPN. Based on data from Patnaik et al. [3], Palomo et al. [4], Breccia et al. [13], Jeromin et al. [15], DiNardo et al. [20], Such et al. [23], Tang et al. [24], Wassie et al. [25], Patnaik et al. [26] and Mangaonkar et al. [27]. Abbreviations: aCML: atypical chronic myeloid leukemia; CMML: chronic myelomonocytic leukemia; MDS/MPN-RS-T: myelodysplastic/myeloproliferative neoplasm with ring sideroblasts and thrombocytosis; MDS/MPNU: myelodysplastic/myeloproliferative neoplasm unclassifiable. 
Table 2. Clinical relevance of cytogenetic abnormalities and gene mutations in MDS/MPN.

\begin{tabular}{|c|c|c|}
\hline MDS/MPN Subtype & Diagnosis & Prognosis \\
\hline CMML & $\begin{array}{l}\text {-WHO [1]: presence of mutations in genes } \\
\text { often associated with CMML (TET2, SRSF2, } \\
\text { ASXL1, SETBP1) in the proper clinical contest } \\
\text { can be used to support diagnosis } \\
\text {-Associated with the following gene mutation } \\
\text { combinations: TET2-SRSF2, biallelic TET2, } \\
\text { SRSF2-RUNX1 }[2,4,30]\end{array}$ & 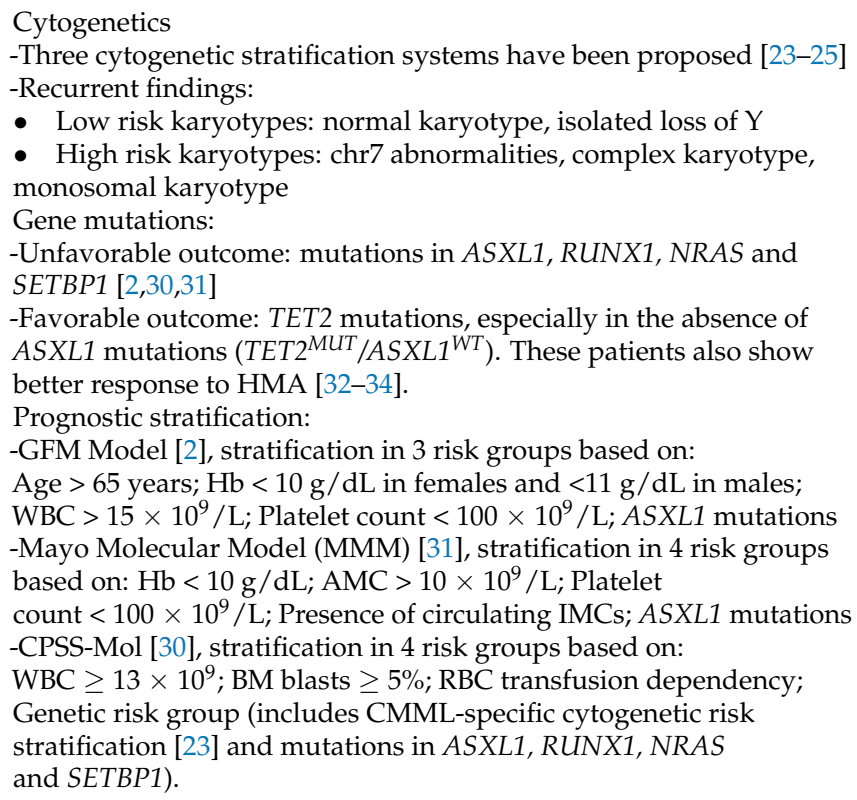 \\
\hline aCML & $\begin{array}{l}\text {-Associated with the following gene mutation } \\
\text { combinations: ASXL1/SETBP1, SETBP1/SRSF2, } \\
\text { ASXL1/EZH2, RUNX1/EZH2 [3,4,35] }\end{array}$ & $\begin{array}{l}\text { Unfavorable outcome: mutations in TET2, RUNX1, NRAS and } \\
\text { CUX1 [3,4] } \\
\text { Prognostic stratification: } \\
\text { Mayo Prognostic Model for aCML [3], stratification in } 2 \text { risk groups } \\
\text { based on: Age }>67 \text { years; } \mathrm{Hb}<10 \mathrm{~g} / \mathrm{dL} ; \text { TET2 mutations }\end{array}$ \\
\hline MDS/MPN-RS-T & $\begin{array}{l}\text {-WHO [1]: presence of a SF3B1 mutation. } \\
\text {-Associated with the following gene mutation } \\
\text { combinations: } S F 3 B 1 \text {, either alone or in } \\
\text { combination with } D N M T 3 A \text { or } J A K 2 \text {, or } \\
\text { DNMT3A/JAK2 [4,26,36] }\end{array}$ & $\begin{array}{l}\text { Unfavorable outcome: } \\
\text {-Presence of altered karyotype [4,26] } \\
\text {-Mutations in } A S X L 1, S E T B P 1, E Z H 2[4,26] \\
\text { Prognostic stratification: } \\
\text { Mayo Prognostic Model for MDS/MPN-RS-T [26], stratification in } \\
3 \text { risk groups based on: } \mathrm{Hb}<10 \mathrm{~g} / \mathrm{dL} ; \text { Abnormal karyotype; } \\
\text { mutations in } A S X L 1 \text { or } S E T B P 1\end{array}$ \\
\hline
\end{tabular}

\section{Unfavorable outcome:}

-Presence of chr7 abnormalities and complex karyotypes [19]

MDS/MPN-U

-Mutations in ASXL1, CBL, CEBPA, EZH2, STAG2, TP53 [4,27,37]

Prognostic stratification:

-Genomics-based stratification system (Figure 4), classification in

5 subtypes with prognostic relevance based on mutational profile [4]

\section{Prognostic stratification:}

-WHO [1]: presence of (1 finding sufficient): According to the methylation level, three groups that correlate molecular features and clinical outcome have been proposed [38]:

- Somatic mutation: PTPN11, KRAS, NRAS

JMML

- Clinical diagnosis of NF1 or NF1 mutation

- Germline CBL mutation CBL LOH

- High: characterized by somatic PTPN11 mutations and poor clinical outcome

- Intermediate: enriched in somatic KRAS mutations and monosomy 7

- Low: characterized by somatic NRAS and CBL mutations and a favorable prognosis

Abbreviations: aCML: atypical chronic myeloid leukemia; AMC: absolute monocyte count; chr: chromosome; CMML: chronic myelomonocytic leukemia; CPSS-Mol: molecular CMML-specific prognostic scoring system; GFM: Groupe Francophone des Myelodysplasies; Hb: Hemoglobin; HMA: hypomethylating agents; HSCT: hematopoietic stem cell transplantation; IMCs: immature myeloid cells; JMML: juvenile myelomonocytic leukemia; LOH: loss of heterozygosity; MDS/MPN-RS-T: myelodysplastic/myeloproliferative neoplasm with ring sideroblasts and thrombocytosis; MDS/MPN-U: myelodysplastic/myeloproliferative neoplasm unclassifiable; RBC: red blood cells; WBC: white blood cell count; WHO: World Health Organization.

Cytogenetic studies of JMML show a normal karyotype in approximately $65-80 \%$ of cases $[21,39,40]$. Monosomy 7 is the most frequent alteration, reported in $9-25 \%$ of the cases. Other aberrations (such as $\operatorname{del}(7 q)$ and +8 ) are reported in $10 \%$ of cases [21,39]. It is to note that -7 is most often seen in $K R A S$-mutated cases [22]. 


\section{Other Chromosomal Abnormalities}

As previously mentioned, the karyotype is often normal across all MDS/MPN subtypes [1]. Studies using single nucleotide polymorphism arrays (SNP-A) or other techniques that allow the detection of cryptic CNAs and copy number neutral loss of heterozygosity (LOH) are limited. To date, most of these studies report MDS/MPN cases (mainly CMML) within heterogeneous cohorts including other myeloid malignancies [41-43]. Overall, SNP-A allows the detection of chromosomal alterations in $75 \%$ of MDS/MPN patients compared to $30-40 \%$ by conventional cytogenetics [41-46].

Two SNP-A studies performed in large cohorts of CMML patients with normal karyotype reported $40-65 \%$ of abnormalities (CNAs $+\mathrm{LOH})$ in these patients [45,46]. According to these studies, CNAs are detected in one third of patients but are highly heterogeneous, with very few recurrent alterations, including gains in 21q22 and losses in 4q24 and 12p13.2. In contrast, large interstitial LOH regions are detected in $25-35 \%$ of cases, recurrently affect $4 \mathrm{q}, 7 \mathrm{q}$ and $11 \mathrm{q}$, and are often accompanied by the presence of homozygous mutations in TET2, EZH2 and CBL, respectively. Prognostic impact of these abnormalities remains unclear.

Besides CMML, LOH were also reported in 38\% MDS/MPN-U, especially in 11q23.3 were $C B L$ gene is located [44]. Similarly, Jankowska et al. described that $\mathrm{LOH}$ of chromosome 4q (where TET2 gene is located) was frequent in CMML and in secondary AML arising from these cases; however, it was absent in refractory anemia with ring sideroblasts and thrombocytosis (current MDS/MPN-RS-T) and aCML patients [47].

Overall, very few cryptic alterations are seen in patients with MDS/MPN, either by SNP-A or sequencing techniques, and these are highly heterogeneous and not specific to any of the subtypes [4]. Thus, even when chromosomal microarray testing is included as a suggested test by the European LeukaemiaNet 2013 and by the Spanish Group of MDS for the diagnosis of primary MDS, it has not been recommended for clinical work-up of myeloid malignancies by the WHO 2017, nor by the NCCN 2017 guidelines [48].

\section{Functional Pathways Affected in MDS/MPN}

The development of next generation sequencing (NGS) techniques has helped to define the molecular landscape of MDS/MPN. More than $90 \%$ of these patients harbor somatic mutations in a group of genes that is common across the spectrum of myeloid neoplasms [4]. Pediatric entity JMML, considered a RASopathy, is primarily characterized by germline and somatic mutations in genes involved in the RAS pathway [38]. In contrast, the spectrum of gene mutations in adult MDS/MPN is much more heterogeneous, with driver genes affecting specific cellular processes that can be categorized according to their function. Mutations recurrently affect epigenetic regulators, splicing factors, genes involved in signaling pathways, transcription factors and cohesin complex components $[2-4,26,37]$ (Figures $1 \mathrm{~B}$ and 2). The acquisition of mutations in these patients occurs in a multi-step manner, as reported in both myeloid and lymphoid neoplasms [49]. Many cases probably arise from previous asymptomatic clonal hematopoiesis, and thus founder driver mutations are frequently found in epigenetic regulators and splicing factors. Secondary acquired driver mutations commonly affect transcription factors and signal transduction genes, which sometimes drive disease progression to AML, along with cell-intrinsic and -extrinsic factors. However, gene mutation frequencies and clonal evolution patterns differ among the four adult MDS/MPN subtypes [4] (Figures 1B and 3).

\subsection{Epigenetic Regulators}

Mutations in epigenetic regulators are very common across the spectrum of myeloid malignancies and constitute the most frequent type of somatic mutations detected in MDS/MPN, seen in up to $75 \%$ of adult overlap syndromes [4]. They can be divided into DNA methylation enzymes (TET2, DNMT3A and, less frequently, IDH2) and chromatin modifiers (ASXL1, EZH2). Epigenetic regulators are commonly affected by missense, nonsense and frameshift loss-of-function mutations that are usually located throughout the 
gene, sometimes affecting hotspots [55]. Mutations in DTA genes (DNMT3A, TET2, ASXL1) account for the majority of mutation-driven clonal hematopoiesis of indeterminate potential (CHIP), thus representing an early driver event for hematological neoplasia $[49,56]$.

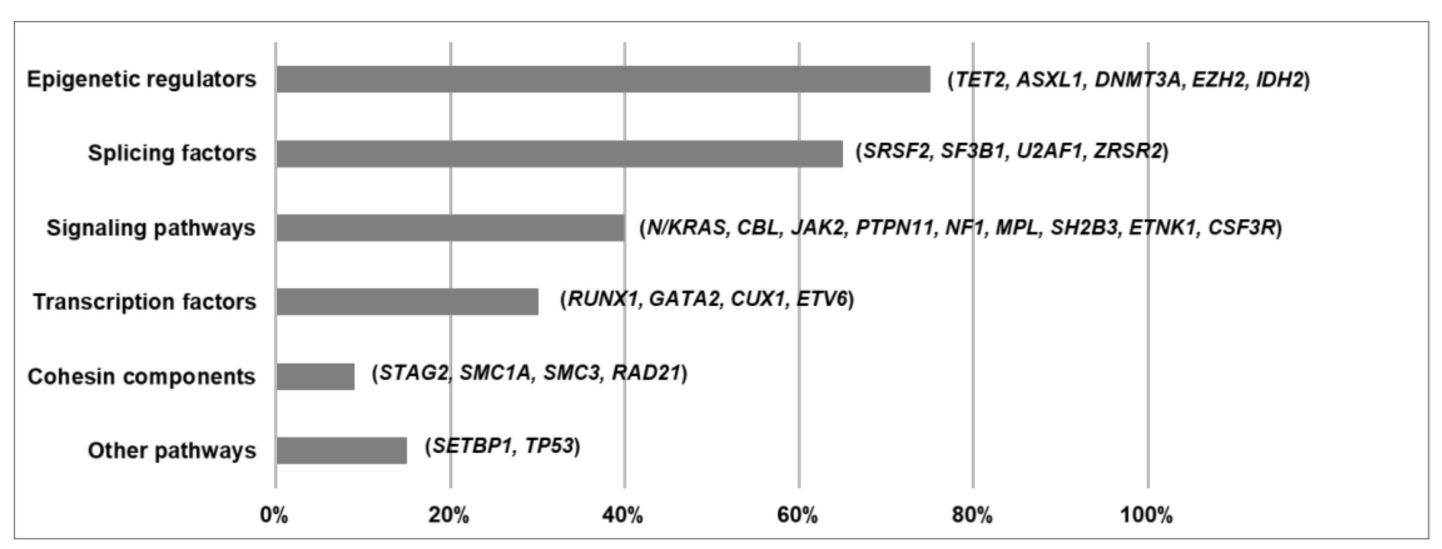

Figure 2. Functional pathways affected in MDS/MPN. Frequency of mutations affecting each pathway/functional category in MDS/MPN overlap syndromes. Based on data from Itzykson et al. [2], Patnaik et al. [3], Palomo et al. [4], Patnaik et al. [26] and Bose et al. [37].

TET2 mutations are very frequent in MDS/MPN (30-40\%) and, more specifically, CMML (60-65\%). In fact, Tet2 deficient mice develop myeloid neoplasia with a CMML-like phenotype [57]. TET2 encodes an enzyme that catalyzes the conversion of the modified DNA base methylcytosine to 5-hydroxymethylcytosine which plays a role in normal myelopoiesis. Deleterious mutations disrupt this enzymatic activity favoring myeloid tumorigenesis [58]. TET2 mutations are associated with advanced age, clonal hematopoiesis and normal karyotype, probably constituting early pathogenic mutations associated with the ageing of hematopoietic stem cells [59]. They are mutually exclusive with IDH1/2 mutations and often coexist with 4q24 LOH or mutations in SRSF2 or EZH2, especially in CMML $[59,60]$.

$D N M T 3 A$ is mutated in $10 \%$ of MDS/MPN, with a higher prevalence in patients with advanced age. DNMT3A mutations account for $50 \%$ of all clonal hematopoiesis mutations and are considered an early genetic event in disease-initiation process that confers a clonal advantage to the hematopoietic cells $[61,62]$. DNMT3A encodes the DNA methyltransferase responsible for the conversion of cytosine to 5-methylcytosine. Mutations result in an enzyme with reduced activity that commonly displays a dominant-negative effect [63]. They are associated with normal karyotype and are often co-mutated with SF3B1 in patients with ring sideroblasts $[4,64]$.

ASXL1 disruptive mutations are seen in $40-50 \%$ of MDS/MPN and are especially prevalent in aCML (50-70\%) and CMML (40-45\%). ASXL1 encodes a nuclear protein that plays a role in gene expression and chromatin remodeling, through the interaction with polycomb repressive complex 2 (PRC2) and transcription activators and repressors [65]. ASXL1 mutations result in loss of epigenetic marks, promoting gene repression and myeloid transformation [66]. In MDS/MPN, they are frequently accompanied by other somatic mutations (EZH2, PTPN11, SETBP1, SRSF2, STAG2, N/KRAS) and they are associated with advanced disease features, such as leukocytosis or higher blast percentage [2,4,37].

$E Z H 2$ mutations are detected in $15 \%$ of MDS/MPN and, more specifically, $25 \%$ of aCML. EZH2 encodes the main catalytic subunit of the PRC2 complex, which has methyltransferase activity, and is considered to act as a tumor suppressor in myeloid malignancies [67]. The presence of loss-of-function mutations in EZH2 is associated with deletions and $\mathrm{LOH}$ of chromosome 7q $[67,68]$. 


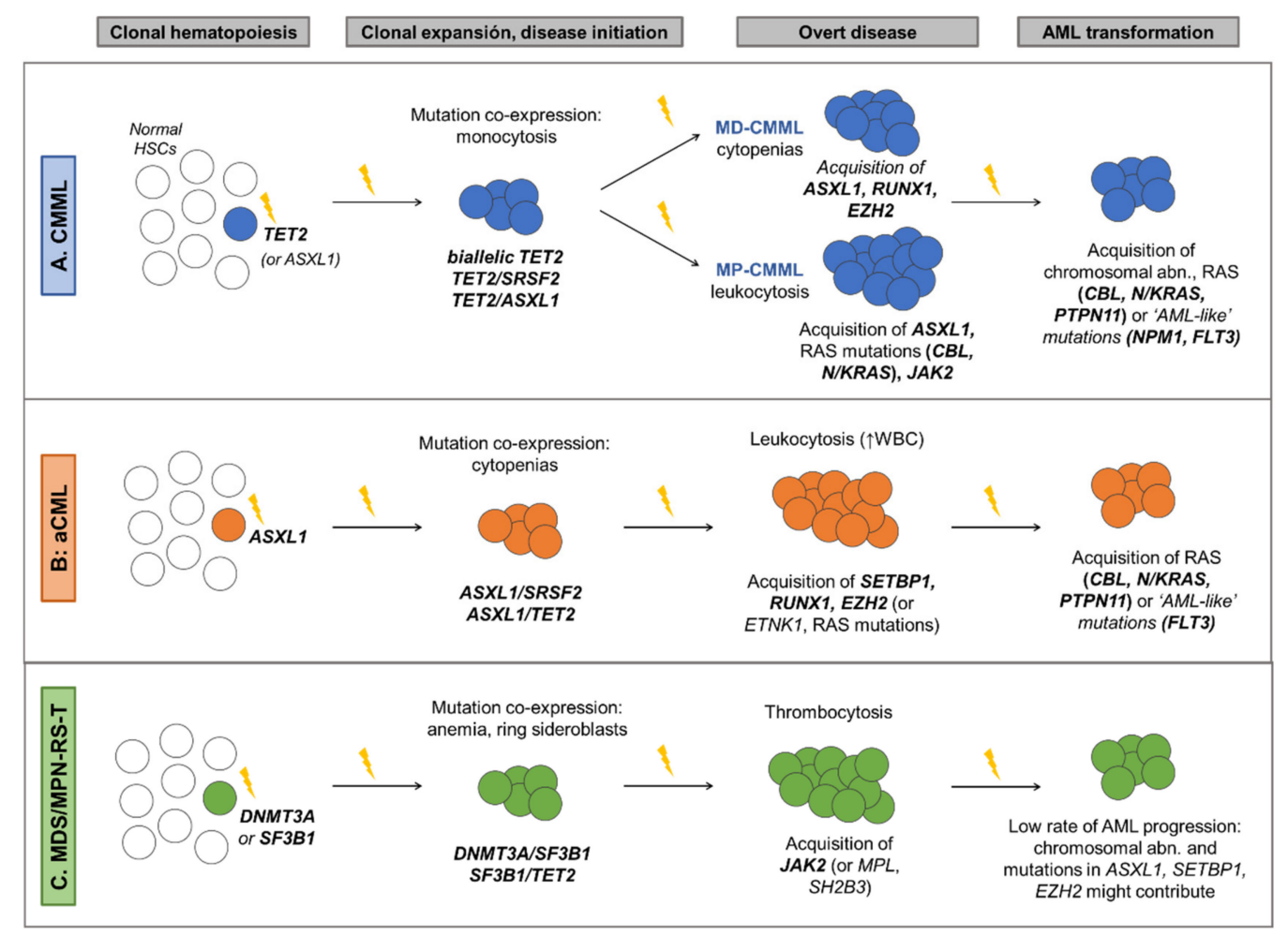

Figure 3. Clonal evolution model in adult MDS/MPN. The figure depicts the clonal evolution patterns most frequently observed in CMML (A), aCML (B) and MDS/MPN-RS-T (C). MDS/MPN arise from asymptomatic clonal hematopoiesis. Over time there is clonal expansion that leads to MDS/MPN phenotype and overt disease that, in some cases, eventually progresses to AML. This process takes place through the acquisition of molecular hits (chromosomal abnormalities and gene mutations) that confer to the neoplastic clone a selective advantage. The type of mutations and the order in which they are acquired shapes the disease phenotype and influences the clinical outcome. Based on data from Itzykson et al. [2], Palomo et al. [4], Elena et al. [30], Patnaik et al. [31], Coltro et al. [32], Palomo et al. [33], Meggendorfer et al. [35], Patnaik et al. [26], Steensma et al. [49], Itzykson et al. [50], Ricci et al. [51], Mason et al. [52], Awada et al. [53] and Patel et al. [54]. Abbreviations: aCML: atypical chronic myeloid leukemia; AML: acute myeloid leukemia; CMML: chronic myelomonocytic leukemia; HSCs: hematopoietic stem cells; MD-CMML: myelodysplastic CMML; MDS/MPN-RS-T: myelodysplastic/myeloproliferative neoplasm with ring sideroblasts and thrombocytosis; MDS/MPNU: myelodysplastic/myeloproliferative neoplasm unclassifiable; MP-CMML: myeloproliferative CMML; WBC: white blood cell count.

\subsection{Splicing Factors}

The spliceosome is a protein complex involved in the splicing process (intron removal) and the generation of a mature mRNA. Mutations in RNA-splicing machinery are associated with the presence of myelodysplasia, thus they are frequently detected in MDS and MDS/MPN and less commonly in AML and MPN [69]. Recurrent mutations have been reported in MDS/MPN in the spliceosome components SF3B1, SRSF2, U2AF1 and ZRSR2, affecting overall up to $65 \%$ of cases, while mutations in PRPF40B, SF3A1, SF1 and $U 2 A F 2$ are rare $(<3 \%)$. Splicing factor mutations are mostly mutually exclusive missense heterozygous mutations localized at hotspot regions, that result in altered patterns of splicing that alter normal hematopoietic differentiation [69-72].

SRSF2 mutations, mainly localized at hotspot P95, are seen in 30\% of MDS/MPN and, more specifically, CMML (50\%). They contribute to myelodysplasia by mutant-specific effects on exon recognition, altering SRSF2 normal sequence-specific RNA binding activity and driving mis-splicing of key hematopoietic regulators [71]. They frequently co-occur with TET2 mutations, especially in CMML, and they are associated with monocytosis and marked thrombocytopenia [2,4,69]. 
SF3B1 mutations are detected overall in 25\% of MDS/MPN, but they are highly specific of MDS/MPN-RS-T (90\%) [26]. SF3B1 mutations are associated with down-regulation of key gene networks involved in hematopoiesis, and most recurrent K700E mutation has been demonstrated to cause impaired erythropoiesis [72,73]. SF3B1 mutations are a clear example of a genotype-phenotype correlation, since they are detected in up to $90 \%$ of patients with ring sideroblasts (MDS/MPN-RS-T and MDS-RS) [73,74].

U2AF1 and ZRSR2 mutations are seen in $8 \%$ and $4 \%$ of MDS/MPN, respectively. They result in aberrant pre-mRNA splicing and alter normal hematopoiesis $[75,76]$.

\subsection{Signaling Pathways}

Signal transduction is a highly regulated process by which a signal is transmitted through a cell as a series of molecular events, most commonly protein phosphorylation catalyzed by protein kinases, which ultimately regulate cellular processes such as cell proliferation, apoptosis and differentiation. Signal transduction genes are generally affected by gain of function missense mutations in hotspot locus that constitutively activate the given signaling pathway. Up to $40 \%$ of MDS/MPN overlap syndromes harbor this type of mutation, which are usually associated with cytokine deregulation and inflammation. Mutations affecting signaling pathways are commonly acquired throughout disease evolution, constituting secondary events that, in many cases, drive disease progression to more advanced proliferative stages and ultimately AML $[4,50]$.

Oncogenic RAS pathway is the most frequently affected signaling pathway in MDS/ MPN, with recurrent mutations in NRAS, KRAS, CBL, PTPN11 and NF1. Hyperactive RAS signaling is the main driving event in JMML, which is characterized by the presence of somatic mutations in K/NRAS and PTPN11 in 50\% of patients, and germline mutations in CBL and NF1 [38]. RAS pathway mutations are associated with leukocytosis and extramedullary disease, and thus are also common in aCML and MP-CMML [4,30,51]. In contrast, they are very rare in MDS/MPN-RS-T $(<3 \%)$, which is characterized by the presence of recurrent $J A K 2$ mutations $(35 \%)$ that are associated with thrombocytosis and that constitutively activate the JAK/STAT signaling pathway [74]. Other genes, less frequently mutated in MDS/MPN ( $<5 \%)$, that also codify for kinases and other molecules involved in signal transduction, include CSF3R, ETNK1, SH2B3 and MPL [4].

\subsection{Transcription Factors}

Transcription factors are proteins that bind to DNA-regulatory sequences (enhancers and silencers), usually localized in the $5^{\prime}$-upstream region of target genes, to modulate the rate of gene transcription. Approximately 30\% of MDS/MPN patients harbor somatic loss-of-function mutations in a transcription factor gene, including RUNX1, GATA2, CUX1, ETV6 and, less frequently (<3\%), NPM1, CEBPA and WT1. As a somatic event, they can be present either in the ancestral clone or in subclonal populations and probably constitute driver events that occur after founder mutations in epigenetic regulators and splicing factors [4]. Of note, germline mutations in RUNX1, GATA2 and CEBPA have been reported in myeloid neoplasms with germline predisposition [1].

Deleterious RUNX1 mutations are seen in up to 15\% of MDS/MPN. They are associated with thrombocytopenia and higher BM blast count $[4,30,77]$ (Table 2).

\subsection{Cohesin Components}

The multiprotein cohesin complex is involved in the cohesion of sister chromatids and the post-replicative DNA repair, and it is codified by the genes STAG1/2, SMC1A, SMC3 and $R A D 21$. Loss-of-function nonsense and frameshift mutations in these genes, which are usually mutually exclusive, have been described in myeloid neoplasia [78].

STAG2 is recurrently mutated in up to $8 \%$ of MDS/MPN, while mutations in other components of the cohesin complex are very rare $(<3 \%)[4]$. 


\subsection{Other Functional Pathways}

SETBP1 mutations are found in 15\% of MDS/MPN, with a higher prevalence in aCML $(40 \%)[79,80]$. SETBP1 gene encodes a nuclear protein that inhibits tumor suppressor PP2A phosphatase activity through SET stabilization. Missense mutations in SETBP1 avoid protein degradation, which constitutively inhibits PP2A, promoting an increase in cell proliferation [79]. These mutations usually correspond to secondary events and are associated with leukocytosis, $-7 / \operatorname{del}(7 \mathrm{q})$ and $\mathrm{i}(17)(\mathrm{q} 10)[30,60,81,82]$.

TP53 mutations are, overall, rare in MDS/MPN $(<5 \%)$, although this frequency increases in MDS/MPN-U (12\%) and in therapy-related CMML $[4,83]$. TP53 is a tumor suppressor gene involved in several functions, including DNA damage response, cell cycle arrest, apoptosis and cell senescence. Mutations in TP53 are prevalent across different types of cancer and affect cell survival and proliferation. In myeloid neoplasms they are frequently associated with $\mathrm{CK}$ and commonly accompanied by a loss in the other allele $[84,85]$.

\section{Molecular Landscape of MDS/MPN and Clinical Implications \\ 6.1. Chronic Myelomonocytic Leukemia}

CMML is the most common and thus the best genetically characterized MDS/MPN, with $>90 \%$ patients showing $\geq 1$ mutation frequently affecting TET2 (60\%), SRSF2 (50\%) and ASXL1 (45\%) (Figure 1B). CMML is a disease of aging, and previous studies suggest that it represents the leukemic conversion of the myelomonocytic-lineage-biased aged hematopoietic system, in which mutated co-expression of TET2 and SRSF2 results in clonal hematopoiesis skewed toward monocytosis [52]. In fact, the combination of mutations in these two genes, as well as biallelic TET2 mutations, is commonly present in the founder clone and is highly associated with CMML phenotype $[2,4,32,53]$. Recurrent secondary driver hits that contribute to clonal expansion and disease evolution include RUNX1 (20\%), SETBP1 (12\%) and EZH2 (8\%), which contribute to the MD-CMML phenotype, and ASXL1, seen in both MD an MP-CMML, being more prevalent in the latter $[4,31,32,50,54]$. In contrast, mutations in signaling genes, mainly RAS pathway (30\%) and JAK2 $(10 \%)$ mutations, are associated with MP-CMML, characterized by leukocytosis, splenomegaly, constitutional symptoms, higher number of mutations and reduced survival. Finally, acquisition of RAS pathway mutations or chromosomal abnormalities frequently drive progression to $\mathrm{AML}$, which is reported in $15-30 \%$ of CMML $[8,30,33,51,54]$. Similarly, mutations in AML-related genes, such as NPM1 and FLT3, although very rare, can be acquired during the course of the disease and are highly suggestive of AML transformation [86,87] (Figure 3A).

According to the 2017 WHO Classification, the presence of mutations in genes often associated with CMML, which are detected in the vast majority of patients, can be used to support a CMML diagnosis in the proper clinical context [1]. This is especially useful in cases with mild dysplasia, given the high prevalence of normal karyotypes (up to 75\%), and the fact that reactive sustained monocytosis is often seen in a spectrum of conditions such as chronic inflammation, bacterial (e.g., tuberculosis, listeriosis, bacterial endocarditis) and viral infections (e.g., EBV), post-splenectomy, and autoimmune diseases, which can be present in up to $20 \%$ of CMML patients, reinforcing the role of molecular testing. Moreover, the presence of CMML-associated genotypes (e.g., TET2/SRSF2) can be useful for the differential diagnosis between CMML and other myeloid-related neoplasms which can also present with monocytosis such as CML, MPN or M4 or M5 AML [4]. The inclusion of molecular markers in CMML-specific prognostic scoring systems has allowed to refine previous models. Current models combine classical adverse prognostic factors (age, anemia, thrombocytopenia, leukocytosis, presence of circulating immature myeloid cells or increased blast count) together with cytogenetic and molecular features [2,30,31]. More specifically, mutations in ASXL1 have been consistently associated with unfavorable outcomes and thus are included in all these scores $[2,30,31]$ (Table 2). In addition, molecular CMML-specific prognostic scoring system (CPSS-Mol) also incorporates mutations in RUNX1, NRAS and SETBP1, which are associated with inferior OS and higher risk of AML transformation [30]. 
In contrast, TET2 mutations are associated with better outcomes, especially in the absence of ASXL1 mutations [32-34]. Furthermore, these patients (TET2 ${ }^{\mathrm{MUT}} / \mathrm{ASXL1}^{\mathrm{WT}}$ ) also show better response to therapy with hypomethylating agents (HMA) [32]. Of note, although HMA therapy can restore hematopoiesis in a subset of CMML patients, which is relevant in the context of cytopenias, it does not decrease mutation allele burden or prevent the acquisition of new genetic alterations, even in responders [88].

\subsection{Atypical Chronic Myeloid Leukemia}

Molecular profile of aCML is heterogeneous, with recurrent mutations in a wide number of genes. It is characterized by a high frequency of mutations in ASXL1 (60-80\%), which commonly constitute major founder initiating events [3,4]. Other recurrent mutations include SETBP1 (40\%), SRSF2 (40\%), TET2 (35\%), EZH2 (25\%), NRAS (20\%), RUNX1 (20\%), GATA2 (18\%), CBL (15\%); 10\% for CSF3R, STAG2 and CUX1; and a long tail of genes mutated in $<10 \%$ of patients $[3,4,35]$ (Figure $1 B$ ). Secondary hits that contribute to clonal expansion and cytopenia development are frequently seen in SETBP1, RUNX1 and EZH2, while subclonal events that promote leukocytosis and drive eventual AML progression frequently affect RAS pathway genes (N/KRAS, CBL, PTPN11 and FLT3) [3,4,35] (Figure 3B).

Although according to WHO criteria aCML can be differentiated from classic CML, CMML, chronic neutrophilic leukemia (CNL) and other MPN mainly on morphological basis, differential diagnosis of aCML is complex [1]. In this scenario, and in the right clinical and morphological context, molecular profiling can inform diagnosis, since specific gene mutation combinations seem to be highly associated with aCML (ASXL1/SETBP1, SETBP1/SRSF2, ASXL1/EZH2 and RUNX1/EZH2) [4]. In contrast, mutations in CSF3R are highly specific of CNL (50-80\%) and, if present in aCML $(\leq 10 \%)$, they are frequently accompanied by ASXL1 and/or SETBP1 mutations [4,89]. Atypical CML is the most aggressive of all overlap syndromes, with a very poor survival and a high transformation rate to AML [90]. Prognostic impact of SETBP1 mutations is controversial $[4,35,79]$, while mutations in TET2, RUNX1, NRAS and CUX1 have been reported to confer poor outcome [3,4]. Mayo Prognostic Model for aCML combines age, anemia and TET2 mutations to stratify patients into two different risk groups that can allow the identification of patients who can benefit from HSCT, which is currently the hallmark of aCML treatment [3].

\subsection{MDS/MPN with Ring Sideroblasts and Thrombocytosis}

Compared to other overlap syndromes, MDS/MPN-RS-T is molecularly the least complex, with normal karyotypes in up to $85 \%$ of patients, lower number of mutations per patient and only a few genes involved in the pathogenesis of the disease [4]. Patients with MDS/MPN-RS-T have both morphological and molecular features of MDS-RS and MPN essential thrombocythemia (ET). This overlap syndrome is characterized by frequent mutations in SF3B1 (90\%), that strongly correlate with BM ring sideroblasts, and mutations in JAK2 $(40 \%)$ that correlate with thrombocytosis [26,74]. However, unlike in ET, CALR mutations are very rare $(<3 \%)[4,36]$. Other recurrent mutations include those associated with clonal hematopoiesis: TET2 (20\%), ASXL1 (20\%) and DNMT3A (15\%); and less frequent mutations in EZH2 (7\%), SETBP1 (5\%) and SRSF2 (5\%) $[4,15,26]$ (Figure 1B). $S F 3 B 1$ mutation is the major driver of the disease, and is recurrently preceded by DNMT3A mutations, that probably constitute a previous asymptomatic clonal hematopoiesis event [4]. Co-expression of SF3B1 with DNMT3A, TET2 or ASXL1 promotes myelodysplasia with ring sideroblasts, while acquisition of $J A K 2$ mutations, and less frequently $M P L(4 \%)$ and SH2B3 (4\%) mutations, constitute secondary events that promote thrombocytosis and contribute to the myeloproliferative phenotype [4,26,36] (Figure 3C).

MDS/MPN-RS-T has a mild course, with longer OS compared to other overlap syndromes and a low rate of AML transformation $(<5 \%)$ [26]. Features such as presence of anemia, history of thrombosis and abnormal karyotype contribute to decreased OS [26,91]. Mutations in ASXL1, SETBP1 and EZH2 have also been associated with adverse outcomes $[4,26]$. Some of these variables are included in Mayo Prognostic Model for 
MDS/MPN-RS-T, which is the only disease-specific prognostic scoring system proposed, that has recently been validated $[4,26]$.

\subsection{MDS/MPN Unclassifiable}

Molecular landscape of MDS/MPN-U is the most heterogeneous, which is expected given that this group includes a variety of poorly defined MDS/MPN that do not meet criteria for other well-defined subtypes, highlighting the complexity of categorization of overlap syndromes. Overall, the most frequent mutations include ASXL1 (40\%), JAK2 (25\%), TET2 (25\%), SRSF2 (25\%), EZH2 (20\%), U2AF1 (16\%) and RUNX1 (15\%) [19,27,37] (Figure 1B). One study recently reported that different molecular profiles could be identified in MDS/MPN-U, which recapitulated molecular signatures that are significantly associated with other MDS/MPN entities [4]. Thus, MDS/MPN-U cases could be further categorized into five molecular subtypes: 'CMML-like' (presence of biallelic TET2, TET2/SRSF2 or RUNX1/SRSF2); 'aCML-like' (presence of any of these gene mutation combinations: ASXL1/SETBP1, SETBP1/SRSF2, ASXL1/EZH2, RUNX1/EZH2); 'MDS/MPNRS-T-like' (SF3B1 mutation, either alone or in combination with DNMT3A or JAK2; or DNMT3A/JAK2); 'TP53' (presence of TP53 mutations) and 'Other' (Figure 4). Molecular subtypes of MDS/MPN-U displayed hematological BM and PB counts in accordance with their phenotypic group. For example, the 'CMML-like' group displayed increased monocyte count and included a few patients that could be classified as oligomonocytic CMML (monocyte count of 0.5 to $<1 \times 10^{9} / \mathrm{L}, \geq 10 \%$ monocytes) [92]. Similarly, 'MDS/MPN-RST-like' patients displayed a median percentage of RS higher than the other groups and, clinically, behaved similarly to MDS/MPN-RS-T patients, suggesting that it might be worth considering taking the presence of SF3B1 mutations into account in patients with 5-15\% of ring sideroblasts, as in MDS-RS. Moreover, OS was significantly different and mimicked the outcome of the corresponding MDS/MPN counterpart, with the 'MDS/MPN-RS-T-like' category being associated with the highest median OS and the patients within 'TP53' group having the most unfavorable prognosis (Table 2). Of note, the adverse prognostic impact of TP53 had previously been reported in these patients [27]. This genomics-based stratification system could potentially allow for inclusion of MDS/MPN-U patients in disease specific/appropriate clinical trials.

\subsection{Juvenile Myelomonocytic Leukemia}

JMML is currently considered a bona fide RASopathy. Even when clinical and hematological criteria must be evaluated for establishing a diagnosis of JMML, it has been described that around $90 \%$ of patients harbor molecular alterations in one of five RAS pathway genes (PTPN11, NRAS, KRAS, NF1 or CBL), which define genetically and clinically distinct subtypes (Table 3 and Figure 5). These genetic aberrations activate the RAS/MAPK pathway and are mutually exclusive in most cases [1]. Subtypes with mutations in PTPN11, NRAS and KRAS, are characterized by heterozygous somatic gain of function mutations, while JMML harboring mutations in NF1 or CBL are defined by germline RAS disease and acquired biallelic inactivation of respective genes in hematopoietic cells [22]. In approximately $10 \%$ of cases, none of these mutations can be detected and it has been reported that a few of these cases harbor RRAS (GTPase with 50\% homology to the RAS proteins) activating somatic mutations, which give rise to an atypical form of this hematological disorder, rapidly progressing to AML [93].

In addition to the main RAS pathway mutation, secondary abnormalities are present in approximately half of the cases. In $10-15 \%$ of cases, these correspond to second hits in one of the RAS pathway genes (RAS double mutant cases) [95]. SETBP1 mutations are found in $7-9 \%$ of the cases $[39,95]$, followed by mutations affecting components of the PRC2 (EZH2 and ASXL1), that are mutated in 4-7\% of the cases [95-97]. Finally, JAK3 mutations are also reported in 3-10\% of JMML patients [39,95,97,98]. Secondary mutations are often subclonal and may be involved in disease progression rather than initiation of leukemia $[95,97,99]$. 


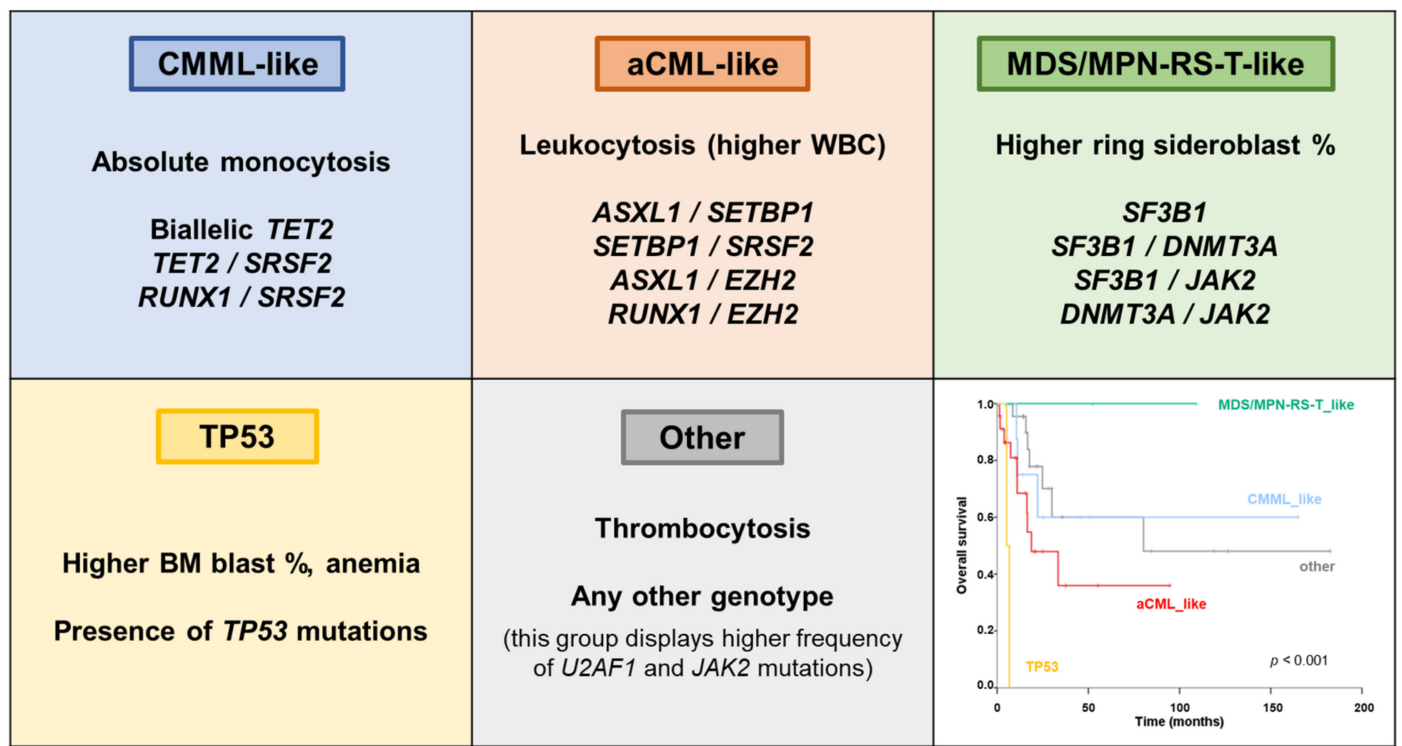

Figure 4. Molecular subtypes of MDS/MPN-U. Molecular classification of MDS/MPN-U based on the presence of specific gene mutation combinations. Morphological features of each subtype are also described in the corresponding panel. Overall survival of molecular subtypes is depicted at the bottom right corner. Based on data from Palomo et al. [4]. Abbreviations: aCML: atypical chronic myeloid leukemia; BM: bone marrow; CMML: chronic myelomonocytic leukemia; MDS/MPN-RS-T: myelodysplastic/myeloproliferative neoplasm with ring sideroblasts and thrombocytosis; WBC: white blood cell count.

Unlike for adult MDS/MPN subtypes, it has been reported that in JMML distinct methylation signatures correlate with clinical and genetic features and are highly predictive of relapse following HSCT $[38,40,100]$. According to the methylation level, three groups that correlate molecular features and clinical outcome have been proposed: the high methylation group, characterized by somatic PTPN11 mutations and poor clinical outcome; the intermediate methylation group, which shows enrichment for somatic KRAS mutations and monosomy 7; and the low methylation group, characterized by enriched for somatic NRAS and CBL mutations and a favorable prognosis [100].

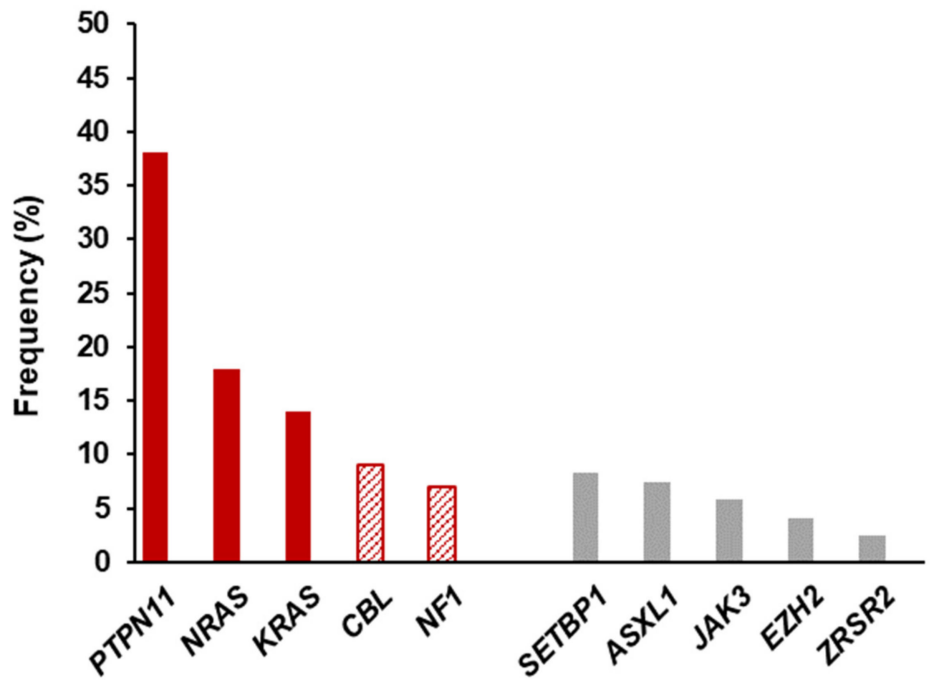

Figure 5. Molecular landscape of JMML. Frequency of recurrent gene mutations in JMML. Red bars represent RAS/MAPK pathway aberrations commonly found in $90 \%$ of the cases. Pattern filled bars represent common germline events. Grey bars depict recurrent subclonal secondary events in the disease. Based on data from Sakaguchi et al. [39], Stieglitz et al. [95], Sugimoto et al. [96], Caye et al. [97] and Bresolin et al. [98]. 
Table 3. Genetic subtypes of JMML with most relevant characteristics.

\begin{tabular}{|c|c|c|c|c|}
\hline $\begin{array}{l}\text { JMML Subtype } \\
\text { and Frequency (\%) }\end{array}$ & $\begin{array}{l}\text { Age of Onset } \\
\text { (Years, Median) }\end{array}$ & Mutation (Type and Location) & Clinical Features & $\begin{array}{l}\text { Prognosis and } \\
\text { Treatment Implications }\end{array}$ \\
\hline PTPN11 (40\%) & 2.1 & $\begin{array}{l}\text { Somatic missense mutations } \\
\text { affecting exons } 3 \text { and } 13 \text {. }\end{array}$ & $\begin{array}{l}\text { Acquisition of NF1 } \\
\text { haploinsufficiency is a } \\
\text { frequent subclonal event. }\end{array}$ & $\begin{array}{l}\text { Rapidly fatal unless allogenic HSCT } \\
\text { can be successfully performed. }\end{array}$ \\
\hline NRAS $(18 \%)$ & 1.2 & $\begin{array}{l}\text { Somatic missense mutations } \\
\text { affecting exon } 2 \text {. }\end{array}$ & $\begin{array}{l}\text { - Subtype with the } \\
\text { highest clinical diversity. } \\
\text { - Clinically, patients are } \\
\text { well and show a normal or } \\
\text { slightly elevated HbF. }\end{array}$ & $\begin{array}{l}\text { Although a considerable } \\
\text { percentage relapse after HSCT, } \\
\text { others survive in its absence and } \\
\text { that of slowly regressing disease. }\end{array}$ \\
\hline KRAS (14\%) & 0.9 & $\begin{array}{l}\text { Somatic missense mutations } \\
\text { affecting exon } 2 \text {. } \\
\text { One half of cases present } \\
\text { monosomy } 7 \text {. }\end{array}$ & $\begin{array}{l}\text { - Most children are } \\
\text { diagnosed before the age } \\
\text { of } 1 \text { year. } \\
\text { - They often present } \\
\text { with particularly } \\
\text { severe disease. }\end{array}$ & $\begin{array}{l}\text { Low relapse rate after } \\
\text { allogeneic HSCT. }\end{array}$ \\
\hline CBL (12-18\%) & 0.9 & $\begin{array}{l}\text { Germline mutations located } \\
\text { throughout the linker and ring } \\
\text { finger domain (intron } 7 \text {, exons } 8 \\
\text { and 9). Most patients have } 11 \mathrm{q} \\
\text { isodisomy in hematopoietic cells. }\end{array}$ & $\begin{array}{l}\text { Most children with } C B L \\
\text { mutations have } \\
\text { self-limiting disease with } \\
\text { persistence of clonal } \\
\text { hematopoiesis. }\end{array}$ & $\begin{array}{l}\text { Observation without therapeutic } \\
\text { intervention is generally advised. } \\
\text { Value of allogenic HSCT } \\
\text { is uncertain }\end{array}$ \\
\hline NF1 (5\%) & 2.8 & $\begin{array}{l}\approx 65 \%: \text { LOH at NF1 locus caused } \\
\text { by UPD of } 17 \mathrm{q} \\
\approx 35 \% \text { : compound heterozygous } \\
\text { NF1 inactivating mutations. } \\
\text { Minority of cases: somatic } \\
\text { interstitial deletions. }\end{array}$ & $\begin{array}{l}\text { - Higher platelet count. } \\
\text { - Higher percentage of } \\
\text { bone marrow blasts. }\end{array}$ & $\begin{array}{l}\text { Invariably fatal unless allogenic } \\
\text { HSCT is successful. }\end{array}$ \\
\hline
\end{tabular}

Information adapted from Niemeyer, 2018 and Niemeyer and Flotho, 2019 [22,94]. Abbreviations: HbF: fetal hemoglobin. HSCT: hematopoietic stem cell transplantation. JMML: juvenile myelomonocytic leukemia. LOH: loss of heterozygosity. UPD: uniparental disomy.

\section{Practical Consideration within the Clinical Context}

It has been widely demonstrated within this review that genetic alterations play a role in the clinical heterogeneity of MDS/MPN neoplasms. NGS has revolutionized the field from every clinical point of view: diagnosis, prognosis and therapeutic management. In general, the finding of a given somatic mutation provides evidence of clonal hematopoiesis, which in the appropriate clinical context, and always complemented by traditional cytomorphological analyses, might guide patient's diagnosis [1,49]. Molecular studies are also interesting in guiding treatment decisions, especially through prognostic evaluation. It has been suggested that prognostic scoring systems could be improved by incorporating information on molecular abnormalities, and in fact current CMML prognostic scoring systems already incorporate this type of information [2,30,31]. Moreover, pretransplant molecular mutation analysis can help to detect biomarkers in patients with MDS/MPN, which may be subsequently used as minimal residual disease markers after HSCT [101].

It is true that NGS is a relatively expensive technique compared to conventional ones, therefore, it seems essential to evaluate the economic impact of the use of this technology. However, if we consider those cases where NGS can potentially shed light on therapeutic decisions such as treatment intensity, HSCT decision or identification of candidates for clinical trials, the cost of such technique might be traduced into patient's management benefit $[102,103]$. Although the approaches to financing health care are extremely diverse and are country specific, the increasingly widespread use of NGS would ultimately impact on lowering costs.

Given the high molecular heterogeneity in MDS/MPN, the new genotype-phenotype associations that are being found and those that are yet to be discovered invite us to consider machine learning as a future tool to help us integrate this large amount of information. It is not expected that sequencing or even artificial intelligence could replace conventional techniques nor clinicians and scientists' expertise, but it would help us to 
integrate all the data and consequently to establish associations more quickly and with higher accuracy [104-106].

\section{Conclusions}

Our understanding of hematological malignancies is inevitably associated with the progress of molecular genetics. In MDS/MPN, the vast majority of patients are affected by gene mutations that have an impact on the pathophysiological features of the disease and play a role in their clinical heterogeneity. However, the spectrum of mutations is heterogeneous, the driver genes are not specific to MDS/MPN, and some of these mutations can be present in individuals with CHIP. Given the high percentage of individuals with this condition, a somatic mutation is not sufficient to diagnose a myeloid neoplasia and it should be interpreted in conjunction with clinical context. Therefore, the diagnosis of MDS/MPN syndromes remains heavily reliant on BM and PB morphology, and although there is no substitute for morphology or pathology, incorporation of molecular data has a potential role in the diagnosis of overlap syndromes. Despite that the spectrum of mutated genes is similar between the different MDS/MPN and even with other myeloid neoplasms, co-expression of specific gene mutations can be suggestive of a given MDS/MPN phenotype, as reviewed above, and can therefore inform diagnosis in the right clinical and morphological context.

MDS/MPN are clinically very heterogeneous. Even in each specific MDS/MPN entity, OS range is wide, and so risk stratification is necessary to identify patients with poor outcome, that are at risk of leukemic transformation and that might benefit from more intensive therapies. In this context, gene mutations play an important role, since they can add prognostic value to classical prognostic factors. For instance, ASXL1 mutations are independently associated with a poor outcome in the spectrum of myeloid neoplasms, including a shorter OS and a higher risk of AML progression. In CMML, aCML and MDS/MPN-RS-T, disease-specific scoring systems have been developed which already include molecular data. In MDS/MPN-U, the most heterogeneous overlap syndrome, a prognostically-relevant molecular classification has been recently proposed. All these prognostic stratifications could inform appropriate clinical therapeutic strategies and appropriate need and timing for allogeneic HSCT. Unfortunately, only selected MDS/MPN patients may undergo HSCT due to their advanced age and/or comorbidities [7,107,108]. Furthermore, only a small proportion of MDS/MPN patients could benefit from targeted therapeutic options, since gene mutations involving genes that are targetable (e.g., IDH1/2, FLT3, TP53) only affect a small subset of patients ( $<5 \%)$. Therefore, therapeutic options in MDS/MPN are still limited, and newer drugs and treatment modalities are much needed for the correct clinical management of these patients.

Author Contributions: L.P.; P.A. and F.S. wrote, reviewed and edited the manuscript. All authors have read and agreed to the published version of the manuscript.

Funding: This research received no external funding.

Acknowledgments: The research carried out in our group is supported in part by a grant from the Instituto de Salud Carlos III, Ministerio de Economia y Competividad, Spain (PI/ 17/0575); by the grant 2017 SGR288 (GRC) Generalitat de Catalunya; with economical support from CERCA Programme/Generalitat de Catalunya, Fundació Internacional Josep Carreras and "la Caixa” Foundation.

Conflicts of Interest: The authors declare no conflict of interest.

\section{References}

1. Swerdlow, S.H.; Campo, E.; Harris, N.L.; Jaffe, E.S.; Pileri, S.A.; Stein, H.; Thiele, J. WHO Classification of Tumours of Hematopoietic and Lymphoid Tissues, 4th ed.; IARC: Lyon, France, 2017.

2. Itzykson, R.; Kosmider, O.; Renneville, A.; Gelsi-Boyer, V.; Meggendorfer, M.; Morabito, M.; Berthon, C.; Adès, L.; Fenaux, P.; Beyne-Rauzy, O.; et al. Prognostic Score Including Gene Mutations in Chronic Myelomonocytic Leukemia. JCO 2013, 31, 2428-2436. [CrossRef] [PubMed] 
3. Patnaik, M.M.; Barraco, D.; Lasho, T.L.; Finke, C.M.; Reichard, K.; Hoversten, K.P.; Ketterling, R.P.; Gangat, N.; Tefferi, A. Targeted next Generation Sequencing and Identification of Risk Factors in World Health Organization Defined Atypical Chronic Myeloid Leukemia. Am. J. Hematol. 2017, 92, 542-548. [CrossRef] [PubMed]

4. Palomo, L.; Meggendorfer, M.; Hutter, S.; Twardziok, S.; Ademà, V.; Fuhrmann, I.; Fuster-Tormo, F.; Xicoy, B.; Zamora, L.; Acha, P.; et al. Molecular Landscape and Clonal Architecture of Adult Myelodysplastic/Myeloproliferative Neoplasms. Blood 2020, 136, 1851-1862. [CrossRef] [PubMed]

5. Rollison, D.E.; Howlader, N.; Smith, M.T.; Strom, S.S.; Merritt, W.D.; Ries, L.A.; Edwards, B.K.; List, A.F. Epidemiology of Myelodysplastic Syndromes and Chronic Myeloproliferative Disorders in the United States, 2001-2004, Using Data from the NAACCR and SEER Programs. Blood 2008, 112, 45-52. [CrossRef]

6. Solary, E.; Itzykson, R. How I Treat Chronic Myelomonocytic Leukemia. Blood 2017, 130, 126-136. [CrossRef]

7. Patnaik, M.M.; Tefferi, A. Chronic Myelomonocytic Leukemia: 2020 Update on Diagnosis, Risk Stratification and Management. Am. J. Hematol. 2020, 95, 97-115. [CrossRef]

8. Bennett, J.M.; Catovsky, D.; Daniel, M.T.; Flandrin, G.; Galton, D.A.; Gralnick, H.; Sultan, C.; Cox, C. The Chronic Myeloid Leukaemias: Guidelines for Distinguishing Chronic Granulocytic, Atypical Chronic Myeloid, and Chronic Myelomonocytic Leukaemia. Proposals by the French-American-British Cooperative Leukaemia Group. Br. J. Haematol. 1994, 87, 746-754. [CrossRef]

9. Jaffe, E.S.; Harris, N.L.; Stein, H.; Vardiman, J.W. World Health Organization Classification of Tumours, Pathology and Genetics of Tumours of Haematopoietic and Lymphoid Tissues; IARC Press: Lyon, France, 2001.

10. Such, E.; Germing, U.; Malcovati, L.; Cervera, J.; Kuendgen, A.; Della Porta, M.G.; Nomdedeu, B.; Arenillas, L.; Luño, E.; Xicoy, B.; et al. Development and Validation of a Prognostic Scoring System for Patients with Chronic Myelomonocytic Leukemia. Blood 2013, 121, 3005-3015. [CrossRef]

11. Schuler, E.; Schroeder, M.; Neukirchen, J.; Strupp, C.; Xicoy, B.; Kündgen, A.; Hildebrandt, B.; Haas, R.; Gattermann, N.; Germing, U. Refined Medullary Blast and White Blood Cell Count Based Classification of Chronic Myelomonocytic Leukemias. Leuk. Res. 2014, 38, 1413-1419. [CrossRef]

12. Orazi, A.; Germing, U. The Myelodysplastic/Myeloproliferative Neoplasms: Myeloproliferative Diseases with Dysplastic Features. Leukemia 2008, 22, 1308-1319. [CrossRef]

13. Breccia, M.; Biondo, F.; Latagliata, R.; Carmosino, I.; Mandelli, F.; Alimena, G. Identification of Risk Factors in Atypical Chronic Myeloid Leukemia. Haematologica 2006, 91, 1566-1568.

14. Giri, S.; Pathak, R.; Martin, M.G.; Bhatt, V.R. Characteristics and Survival of BCR/ABL Negative Chronic Myeloid Leukemia: A Retrospective Analysis of the Surveillance, Epidemiology and End Results Database. Ther. Adv. Hematol. 2015, 6, 308-312. [CrossRef]

15. Jeromin, S.; Haferlach, T.; Weissmann, S.; Meggendorfer, M.; Eder, C.; Nadarajah, N.; Alpermann, T.; Kohlmann, A.; Kern, W.; Haferlach, C.; et al. Refractory Anemia with Ring Sideroblasts and Marked Thrombocytosis Cases Harbor Mutations in SF3B1 or Other Spliceosome Genes Accompanied by JAK2V617F and ASXL1 Mutations. Haematologica 2015, 100, e125-e127. [CrossRef]

16. Broseus, J.; Florensa, L.; Zipperer, E.; Schnittger, S.; Malcovati, L.; Richebourg, S.; Lippert, E.; Cermak, J.; Evans, J.; Mounier, M.; et al. Clinical Features and Course of Refractory Anemia with Ring Sideroblasts Associated with Marked Thrombocytosis. Haematologica 2012, 97, 1036-1041. [CrossRef]

17. Atallah, E.; Nussenzveig, R.; Yin, C.C.; Bueso-Ramos, C.; Tam, C.; Manshouri, T.; Pierce, S.; Kantarjian, H.; Verstovsek, S. Prognostic Interaction between Thrombocytosis and JAK2 V617F Mutation in the WHO Subcategories of Myelodysplastic/Myeloproliferative Disease-Unclassifiable and Refractory Anemia with Ringed Sideroblasts and Marked Thrombocytosis. Leukemia 2008, 22, 1295-1298. [CrossRef]

18. Cannella, L.; Breccia, M.; Latagliata, R.; Frustaci, A.; Alimena, G. Clinical and Prognostic Features of Patients with Myelodysplastic/Myeloproliferative Syndrome Categorized as Unclassified (MDS/MPD-U) by WHO Classification. Leuk. Res. 2008, 32, 514-516. [CrossRef]

19. Wang, S.A.; Hasserjian, R.P.; Fox, P.S.; Rogers, H.J.; Geyer, J.T.; Chabot-Richards, D.; Weinzierl, E.; Hatem, J.; Jaso, J.; Kanagal-Shamanna, R.; et al. Atypical Chronic Myeloid Leukemia Is Clinically Distinct from Unclassifiable Myelodysplastic/Myeloproliferative Neoplasms. Blood 2014, 123, 2645-2651. [CrossRef]

20. DiNardo, C.D.; Daver, N.; Jain, N.; Pemmaraju, N.; Bueso-Ramos, C.; Yin, C.C.; Pierce, S.; Jabbour, E.; Cortes, J.E.; Kantarjian, H.M.; et al. Myelodysplastic/Myeloproliferative Neoplasms, Unclassifiable (MDS/MPN, U): Natural History and Clinical Outcome by Treatment Strategy. Leukemia 2014, 28, 958-961. [CrossRef]

21. Niemeyer, C.M.; Arico, M.; Basso, G.; Biondi, A.; Cantu Rajnoldi, A.; Creutzig, U.; Haas, O.; Harbott, J.; Hasle, H.; Kerndrup, G.; et al. Chronic Myelomonocytic Leukemia in Childhood: A Retrospective Analysis of 110 Cases. European Working Group on Myelodysplastic Syndromes in Childhood (EWOG-MDS). Blood 1997, 89, 3534-3543.

22. Niemeyer, C.M.; Flotho, C. Juvenile Myelomonocytic Leukemia: Who's the Driver at the Wheel? Blood 2019, 133, 1060-1070. [CrossRef]

23. Such, E.; Cervera, J.; Costa, D.; Sole, F.; Vallespi, T.; Luno, E.; Collado, R.; Calasanz, M.J.; Hernandez-Rivas, J.M.; Cigudosa, J.C.; et al. Cytogenetic Risk Stratification in Chronic Myelomonocytic Leukemia. Haematologica 2011, 96, 375-383. [CrossRef] [PubMed] 
24. Tang, G.; Zhang, L.; Fu, B.; Hu, J.; Lu, X.; Hu, S.; Patel, A.; Goswami, M.; Khoury, J.D.; Garcia-Manero, G.; et al. Cytogenetic Risk Stratification of 417 Patients with Chronic Myelomonocytic Leukemia from a Single Institution: Cytogenetic Stratification in CMML Patients. Am. J. Hematol. 2014, 89, 813-818. [CrossRef] [PubMed]

25. Wassie, E.A.; Itzykson, R.; Lasho, T.L.; Kosmider, O.; Finke, C.M.; Hanson, C.A.; Ketterling, R.P.; Solary, E.; Tefferi, A.; Patnaik, M.M. Molecular and Prognostic Correlates of Cytogenetic Abnormalities in Chronic Myelomonocytic Leukemia: A Mayo Clinic-French Consortium Study. Am. J. Hematol. 2014, 89, 1111-1115. [CrossRef] [PubMed]

26. Patnaik, M.M.; Lasho, T.L.; Finke, C.M.; Hanson, C.A.; King, R.L.; Ketterling, R.P.; Gangat, N.; Tefferi, A. Predictors of Survival in Refractory Anemia with Ring Sideroblasts and Thrombocytosis (RARS-T) and the Role of next-Generation Sequencing: Predictors of Survival in Refractory Anemia with Ring Sideroblasts and Thrombocytosis. Am. J. Hematol. 2016, 91, 492-498. [CrossRef] [PubMed]

27. Mangaonkar, A.A.; Swoboda, D.M.; Coltro, G.; Lasho, T.L.; Novotny, P.J.; Pophali, P.; Carr, R.M.; Binder, M.; Finke, C.M.; Gangat, N.; et al. Clinicopathologic Characteristics, Prognostication and Treatment Outcomes for Myelodysplastic/Myeloproliferative Neoplasm, Unclassifiable (MDS/MPN-U): Mayo Clinic-Moffitt Cancer Center Study of 135 Consecutive Patients. Leukemia 2020, 34, 656-661. [CrossRef] [PubMed]

28. Pierre, R.V.; Hoagland, H.C. Age-Associated Aneuploidy: Loss of Y Chromosome from Human Bone Marrow Cells with Aging. Cancer 1972, 30, 889-894. [CrossRef]

29. Guttenbach, M.; Koschorz, B.; Bernthaler, U.; Grimm, T.; Schmid, M. Sex Chromosome Loss and Aging: In Situ Hybridization Studies on Human Interphase Nuclei. Am. J. Hum. Genet. 1995, 57, 1143.

30. Elena, C.; Gallì, A.; Such, E.; Meggendorfer, M.; Germing, U.; Rizzo, E.; Cervera, J.; Molteni, E.; Fasan, A.; Schuler, E.; et al. Integrating Clinical Features and Genetic Lesions in the Risk Assessment of Patients with Chronic Myelomonocytic Leukemia. Blood 2016, 128, 1408-1417. [CrossRef]

31. Patnaik, M.M.; Itzykson, R.; Lasho, T.L.; Kosmider, O.; Finke, C.M.; Hanson, C.A.; Knudson, R.A.; Ketterling, R.P.; Tefferi, A.; Solary, E. ASXL1 and SETBP1 Mutations and Their Prognostic Contribution in Chronic Myelomonocytic Leukemia: A Two-Center Study of 466 Patients. Leukemia 2014, 28, 2206-2212. [CrossRef]

32. Coltro, G.; Mangaonkar, A.A.; Lasho, T.L.; Finke, C.M.; Pophali, P.; Carr, R.; Gangat, N.; Binder, M.; Pardanani, A.; FernandezZapico, M.; et al. Clinical, Molecular, and Prognostic Correlates of Number, Type, and Functional Localization of TET2 Mutations in Chronic Myelomonocytic Leukemia (CMML)-a Study of 1084 Patients. Leukemia 2020, 34, 1407-1421. [CrossRef]

33. Palomo, L.; Garcia, O.; Arnan, M.; Xicoy, B.; Fuster, F.; Cabezón, M.; Coll, R.; Ademà, V.; Grau, J.; Jiménez, M.-J.; et al. Targeted Deep Sequencing Improves Outcome Stratification in Chronic Myelomonocytic Leukemia with Low Risk Cytogenetic Features. Oncotarget 2016, 7. [CrossRef]

34. Patnaik, M.M.; Lasho, T.L.; Vijayvargiya, P.; Finke, C.M.; Hanson, C.A.; Ketterling, R.P.; Gangat, N.; Tefferi, A. Prognostic Interaction between ASXL1 and TET2 Mutations in Chronic Myelomonocytic Leukemia. Blood Cancer J. 2016, 6, e385. [CrossRef]

35. Meggendorfer, M.; Bacher, U.; Alpermann, T.; Haferlach, C.; Kern, W.; Gambacorti-Passerini, C.; Haferlach, T.; Schnittger, S. SETBP1 Mutations Occur in 9\% of MDS/MPN and in 4\% of MPN Cases and Are Strongly Associated with Atypical CML, Monosomy 7, Isochromosome i(17)(Q10), ASXL1 and CBL Mutations. Leukemia 2013, 27, 1852-1860. [CrossRef]

36. Broséus, J.; Lippert, E.; Harutyunyan, A.S.; Jeromin, S.; Zipperer, E.; Florensa, L.; Milosevic, J.D.; Haferlach, T.; Germing, U.; Luño, E.; et al. Low Rate of Calreticulin Mutations in Refractory Anaemia with Ring Sideroblasts and Marked Thrombocytosis. Leukemia 2014, 28, 1374-1376. [CrossRef]

37. Bose, P.; Nazha, A.; Komrokji, R.S.; Patel, K.P.; Pierce, S.A.; Al-Ali, N.; Sochacki, A.; Shaver, A.; Ma, W.; Su, X.; et al. Mutational Landscape of Myelodysplastic/Myeloproliferative Neoplasm-Unclassifiable. Blood 2018, 132, 2100-2103. [CrossRef]

38. Lipka, D.B.; Witte, T.; Toth, R.; Yang, J.; Wiesenfarth, M.; Nöllke, P.; Fischer, A.; Brocks, D.; Gu, Z.; Park, J.; et al. RAS-Pathway Mutation Patterns Define Epigenetic Subclasses in Juvenile Myelomonocytic Leukemia. Nat. Commun. 2017, 8, 2126. [CrossRef]

39. Sakaguchi, H.; Okuno, Y.; Muramatsu, H.; Yoshida, K.; Shiraishi, Y.; Takahashi, M.; Kon, A.; Sanada, M.; Chiba, K.; Tanaka, H.; et al. Exome Sequencing Identifies Secondary Mutations of SETBP1 and JAK3 in Juvenile Myelomonocytic Leukemia. Nat. Genet. 2013, 45, 937-941. [CrossRef]

40. Murakami, N.; Okuno, Y.; Yoshida, K.; Shiraishi, Y.; Nagae, G.; Suzuki, K.; Narita, A.; Sakaguchi, H.; Kawashima, N.; Wang, X.; et al. Integrated Molecular Profiling of Juvenile Myelomonocytic Leukemia. Blood 2018, 131, 1576-1586. [CrossRef]

41. Gondek, L.P.; Dunbar, A.J.; Szpurka, H.; McDevitt, M.A.; Maciejewski, J.P. SNP Array Karyotyping Allows for the Detection of Uniparental Disomy and Cryptic Chromosomal Abnormalities in MDS/MPD-U and MPD. PLoS ONE 2007, 2, e1225. [CrossRef]

42. Gondek, L.P.; Tiu, R.; O'Keefe, C.L.; Sekeres, M.A.; Theil, K.S.; Maciejewski, J.P. Chromosomal Lesions and Uniparental Disomy Detected by SNP Arrays in MDS, MDS/MPD, and MDS-Derived AML. Blood 2008, 111, 1534-1542. [CrossRef]

43. Tiu, R.V.; Gondek, L.P.; O’Keefe, C.L.; Elson, P.; Huh, J.; Mohamedali, A.; Kulasekararaj, A.; Advani, A.S.; Paquette, R.; List, A.F.; et al. Prognostic Impact of SNP Array Karyotyping in Myelodysplastic Syndromes and Related Myeloid Malignancies. Blood 2011, 117, 4552-4560. [CrossRef] [PubMed]

44. Dunbar, A.J.; Gondek, L.P.; O’Keefe, C.L.; Makishima, H.; Rataul, M.S.; Szpurka, H.; Sekeres, M.A.; Wang, X.F.; McDevitt, M.A.; Maciejewski, J.P. 250K Single Nucleotide Polymorphism Array Karyotyping Identifies Acquired Uniparental Disomy and Homozygous Mutations, Including Novel Missense Substitutions of c-Cbl, in Myeloid Malignancies. Cancer Res. 2008, 68, 10349-10357. [CrossRef] [PubMed] 
45. Palomo, L.; Xicoy, B.; Garcia, O.; Mallo, M.; Ademà, V.; Cabezón, M.; Arnan, M.; Pomares, H.; José Larrayoz, M.; José Calasanz, M.; et al. Impact of SNP Array Karyotyping on the Diagnosis and the Outcome of Chronic Myelomonocytic Leukemia with Low Risk Cytogenetic Features or No Metaphases. Am. J. Hematol. 2016, 91, 185-192. [CrossRef] [PubMed]

46. Vetro, C.; Haferlach, C.; Haferlach, T.; Zenger, M.; Nadarajah, N.; Kern, W.; Meggendorfer, M. Aberrations Identified by Genomic Arrays in Normal Karyotype CMML Can Be Detected in 40\% of Patients, but Do Not Add Prognostic Information to Molecular Mutations. Leukemia 2016, 30, 2235-2238. [CrossRef]

47. Jankowska, A.M.; Szpurka, H.; Tiu, R.V.; Makishima, H.; Afable, M.; Huh, J.; O’Keefe, C.L.; Ganetzky, R.; McDevitt, M.A.; Maciejewski, J.P. Loss of Heterozygosity 4q24 and TET2 Mutations Associated with Myelodysplastic/Myeloproliferative Neoplasms. Blood 2009, 113, 6403-6410. [CrossRef] [PubMed]

48. Kanagal-Shamanna, R.; Hodge, J.C.; Tucker, T.; Shetty, S.; Yenamandra, A.; Dixon-McIver, A.; Bryke, C.; Huxley, E.; Lennon, P.A.; Raca, G.; et al. Assessing Copy Number Aberrations and Copy Neutral Loss of Heterozygosity across the Genome as Best Practice: An Evidence Based Review of Clinical Utility from the Cancer Genomics Consortium (CGC) Working Group for Myelodysplastic Syndrome, Myelodysplastic/Myeloproliferative and Myeloproliferative Neoplasms. Cancer Genet. 2018, 228-229, 197-217. [CrossRef]

49. Steensma, D.P.; Bejar, R.; Jaiswal, S.; Lindsley, R.C.; Sekeres, M.A.; Hasserjian, R.P.; Ebert, B.L. Clonal Hematopoiesis of Indeterminate Potential and Its Distinction from Myelodysplastic Syndromes. Blood 2015, 9-16. [CrossRef] [PubMed]

50. Itzykson, R.; Kosmider, O.; Renneville, A.; Morabito, M.; Preudhomme, C.; Berthon, C.; Adès, L.; Fenaux, P.; Platzbecker, U.; Gagey, O.; et al. Clonal Architecture of Chronic Myelomonocytic Leukemias. Blood 2013, 121, 2186-2198. [CrossRef]

51. Ricci, C.; Fermo, E.; Corti, S.; Molteni, M.; Faricciotti, A.; Cortelezzi, A.; Lambertenghi Deliliers, G.; Beran, M.; Onida, F. RAS Mutations Contribute to Evolution of Chronic Myelomonocytic Leukemia to the Proliferative Variant. Clin. Cancer Res. 2010, 16, 2246-2256. [CrossRef]

52. Mason, C.C.; Khorashad, J.S.; Tantravahi, S.K.; Kelley, T.W.; Zabriskie, M.S.; Yan, D.; Pomicter, A.D.; Reynolds, K.R.; Eiring, A.M.; Kronenberg, Z.; et al. Age-Related Mutations and Chronic Myelomonocytic Leukemia. Leukemia 2016, 30, 906-913. [CrossRef]

53. Awada, H.; Nagata, Y.; Goyal, A.; Asad, M.F.; Patel, B.; Hirsch, C.M.; Kuzmanovic, T.; Guan, Y.; Przychodzen, B.P.; Aly, M.; et al. Invariant Phenotype and Molecular Association of Biallelic TET2 Mutant Myeloid Neoplasia. Blood Adv. 2019, 3, 339-349. [CrossRef]

54. Patel, B.J.; Przychodzen, B.; Thota, S.; Radivoyevitch, T.; Visconte, V.; Kuzmanovic, T.; Clemente, M.; Hirsch, C.; Morawski, A.; Souaid, R.; et al. Genomic Determinants of Chronic Myelomonocytic Leukemia. Leukemia 2017, 31, 2815-2823. [CrossRef]

55. Shih, A.H.; Abdel-Wahab, O.; Patel, J.P.; Levine, R.L. The Role of Mutations in Epigenetic Regulators in Myeloid Malignancies. Nat. Rev. Cancer 2012, 12, 599-612. [CrossRef]

56. Jaiswal, S.; Fontanillas, P.; Flannick, J.; Manning, A.; Grauman, P.V.; Mar, B.G.; Lindsley, R.C.; Mermel, C.H.; Burtt, N.; Chavez, A.; et al. Age-Related Clonal Hematopoiesis Associated with Adverse Outcomes. N. Engl. J. Med. 2014, 371, $2488-2498$. [CrossRef]

57. Moran-Crusio, K.; Reavie, L.; Shih, A.; Abdel-Wahab, O.; Ndiaye-Lobry, D.; Lobry, C.; Figueroa, M.E.; Vasanthakumar, A.; Patel, J.; Zhao, X.; et al. Tet2 Loss Leads to Increased Hematopoietic Stem Cell Self-Renewal and Myeloid Transformation. Cancer Cell 2011, 20, 11-24. [CrossRef]

58. Ko, M.; Huang, Y.; Jankowska, A.M.; Pape, U.J.; Tahiliani, M.; Bandukwala, H.S.; An, J.; Lamperti, E.D.; Koh, K.P.; Ganetzky, R.; et al. Impaired Hydroxylation of 5-Methylcytosine in Myeloid Cancers with Mutant TET2. Nature 2010, 468, 839-843. [CrossRef]

59. Delhommeau, F.; Dupont, S.; Della Valle, V.; James, C.; Trannoy, S.; Massé, A.; Kosmider, O.; Le Couedic, J.-P.; Robert, F.; Alberdi, A.; et al. Mutation in TET2 in Myeloid Cancers. N. Engl. J. Med. 2009, 360, 2289-2301. [CrossRef]

60. Damm, F.; Itzykson, R.; Kosmider, O.; Droin, N.; Renneville, A.; Chesnais, V.; Gelsi-Boyer, V.; de Botton, S.; Vey, N.; Preudhomme, C.; et al. SETBP1 Mutations in 658 Patients with Myelodysplastic Syndromes, Chronic Myelomonocytic Leukemia and Secondary Acute Myeloid Leukemias. Leukemia 2013, 27, 1401-1403. [CrossRef]

61. Walter, M.J.; Ding, L.; Shen, D.; Shao, J.; Grillot, M.; McLellan, M.; Fulton, R.; Schmidt, H.; Kalicki-Veizer, J.; O'Laughlin, M.; et al. Recurrent DNMT3A Mutations in Patients with Myelodysplastic Syndromes. Leukemia 2011, 25, 1153-1158. [CrossRef]

62. Buscarlet, M.; Provost, S.; Zada, Y.F.; Barhdadi, A.; Bourgoin, V.; Lépine, G.; Mollica, L.; Szuber, N.; Dubé, M.-P.; Busque, L. DNMT3A and TET2 Dominate Clonal Hematopoiesis and Demonstrate Benign Phenotypes and Different Genetic Predispositions. Blood 2017, 130, 753-762. [CrossRef]

63. Kim, S.J.; Zhao, H.; Hardikar, S.; Singh, A.K.; Goodell, M.A.; Chen, T. A DNMT3A Mutation Common in AML Exhibits Dominant-Negative Effects in Murine ES Cells. Blood 2013, 122, 4086-4089. [CrossRef]

64. Martín, I.; Such, E.; Navarro, B.; Vicente, A.; López-Pavía, M.; Ibáñez, M.; Tormo, M.; Villamón, E.; Gómez-Seguí, I.; Luna, I.; et al. Negative Impact on Clinical Outcome of the Mutational Co-Occurrence of SF3B1 and DNMT3A in Refractory Anemia with Ring Sideroblasts (RARS). Leuk Lymphoma 2017, 58, 1686-1693. [CrossRef]

65. Gelsi-Boyer, V.; Brecqueville, M.; Devillier, R.; Murati, A.; Mozziconacci, M.-J.; Birnbaum, D. Mutations in ASXL1 Are Associated with Poor Prognosis across the Spectrum of Malignant Myeloid Diseases. J. Hematol. Oncol. 2012, 5, 12. [CrossRef]

66. Abdel-Wahab, O.; Adli, M.; LaFave, L.M.; Gao, J.; Hricik, T.; Shih, A.H.; Pandey, S.; Patel, J.P.; Chung, Y.R.; Koche, R.; et al. ASXL1 Mutations Promote Myeloid Transformation through Loss of PRC2-Mediated Gene Repression. Cancer Cell 2012, 22, 180-193. [CrossRef] 
67. Ernst, T.; Chase, A.J.; Score, J.; Hidalgo-Curtis, C.E.; Bryant, C.; Jones, A.V.; Waghorn, K.; Zoi, K.; Ross, F.M.; Reiter, A.; et al. Inactivating Mutations of the Histone Methyltransferase Gene EZH2 in Myeloid Disorders. Nat. Genet. 2010, 42, $722-726$. [CrossRef]

68. Jerez, A.; Sugimoto, Y.; Makishima, H.; Verma, A.; Jankowska, A.M.; Przychodzen, B.; Visconte, V.; Tiu, R.V.; O’Keefe, C.L.; Mohamedali, A.M.; et al. Loss of Heterozygosity in 7q Myeloid Disorders: Clinical Associations and Genomic Pathogenesis. Blood 2012, 119, 6109-6117. [CrossRef]

69. Yoshida, K.; Sanada, M.; Shiraishi, Y.; Nowak, D.; Nagata, Y.; Yamamoto, R.; Sato, Y.; Sato-Otsubo, A.; Kon, A.; Nagasaki, M.; et al. Frequent Pathway Mutations of Splicing Machinery in Myelodysplasia. Nature 2011, 478, 64-69. [CrossRef]

70. Makishima, H.; Visconte, V.; Sakaguchi, H.; Jankowska, A.M.; Abu Kar, S.; Jerez, A.; Przychodzen, B.; Bupathi, M.; Guinta, K.; Afable, M.G.; et al. Mutations in the Spliceosome Machinery, a Novel and Ubiquitous Pathway in Leukemogenesis. Blood 2012, 119, 3203-3210. [CrossRef] [PubMed]

71. Kim, E.; Ilagan, J.O.; Liang, Y.; Daubner, G.M.; Lee, S.C.-W.; Ramakrishnan, A.; Li, Y.; Chung, Y.R.; Micol, J.-B.; Murphy, M.E.; et al. SRSF2 Mutations Contribute to Myelodysplasia by Mutant-Specific Effects on Exon Recognition. Cancer Cell 2015, 27, 617-630. [CrossRef]

72. Obeng, E.A.; Chappell, R.J.; Seiler, M.; Chen, M.C.; Campagna, D.R.; Schmidt, P.J.; Schneider, R.K.; Lord, A.M.; Wang, L.; Gambe, R.G.; et al. Physiologic Expression of Sf3b1(K700E) Causes Impaired Erythropoiesis, Aberrant Splicing, and Sensitivity to Therapeutic Spliceosome Modulation. Cancer Cell 2016, 30, 404-417. [CrossRef]

73. Papaemmanuil, E.; Cazzola, M.; Boultwood, J.; Malcovati, L.; Vyas, P.; Bowen, D.; Pellagatti, A.; Wainscoat, J.S.; HellstromLindberg, E.; Gambacorti-Passerini, C.; et al. Somatic SF3B1 Mutation in Myelodysplasia with Ring Sideroblasts. N. Engl. J. Med. 2011, 365, 1384-1395. [CrossRef] [PubMed]

74. Broséus, J.; Alpermann, T.; Wulfert, M.; Florensa Brichs, L.; Jeromin, S.; Lippert, E.; Rozman, M.; Lifermann, F.; Grossmann, V.; Haferlach, T.; et al. Age, JAK2(V617F) and SF3B1 Mutations Are the Main Predicting Factors for Survival in Refractory Anaemia with Ring Sideroblasts and Marked Thrombocytosis. Leukemia 2013, 27, 1826-1831. [CrossRef] [PubMed]

75. Madan, V.; Kanojia, D.; Li, J.; Okamoto, R.; Sato-Otsubo, A.; Kohlmann, A.; Sanada, M.; Grossmann, V.; Sundaresan, J.; Shiraishi, Y.; et al. Aberrant Splicing of U12-Type Introns Is the Hallmark of ZRSR2 Mutant Myelodysplastic Syndrome. Nat. Commun 2015, 6, 6042. [CrossRef] [PubMed]

76. Shirai, C.L.; Ley, J.N.; White, B.S.; Kim, S.; Tibbitts, J.; Shao, J.; Ndonwi, M.; Wadugu, B.; Duncavage, E.J.; Okeyo-Owuor, T.; et al. Mutant U2AF1 Expression Alters Hematopoiesis and Pre-MRNA Splicing In Vivo. Cancer Cell 2015, 27, 631-643. [CrossRef]

77. Cazzola, M.; Della Porta, M.G.; Malcovati, L. The Genetic Basis of Myelodysplasia and Its Clinical Relevance. Blood 2013, 122, 4021-4034. [CrossRef]

78. Kon, A.; Shih, L.-Y.; Minamino, M.; Sanada, M.; Shiraishi, Y.; Nagata, Y.; Yoshida, K.; Okuno, Y.; Bando, M.; Nakato, R.; et al. Recurrent Mutations in Multiple Components of the Cohesin Complex in Myeloid Neoplasms. Nat. Genet. 2013, 45, $1232-1237$. [CrossRef]

79. Piazza, R.; Valletta, S.; Winkelmann, N.; Redaelli, S.; Spinelli, R.; Pirola, A.; Antolini, L.; Mologni, L.; Donadoni, C.; Papaemmanuil, E.; et al. Recurrent SETBP1 Mutations in Atypical Chronic Myeloid Leukemia. Nat. Genet. 2013, 45, 18-24. [CrossRef]

80. Makishima, H.; Yoshida, K.; Nguyen, N.; Przychodzen, B.; Sanada, M.; Okuno, Y.; Ng, K.P.; Gudmundsson, K.O.; Vishwakarma, B.A.; Jerez, A.; et al. Somatic SETBP1 Mutations in Myeloid Malignancies. Nat. Genet. 2013, 45, 942-946. [CrossRef]

81. Hou, H.-A.; Kuo, Y.-Y.; Tang, J.-L.; Chou, W.-C.; Yao, M.; Lai, Y.-J.; Lin, C.-C.; Chen, C.-Y.; Liu, C.-Y.; Tseng, M.-H.; et al. Clinical Implications of the SETBP1 Mutation in Patients with Primary Myelodysplastic Syndrome and Its Stability during Disease Progression. Am. J. Hematol. 2014, 89, 181-186. [CrossRef]

82. Adema, V.; Larráyoz, M.J.; Calasanz, M.J.; Palomo, L.; Patiño-García, A.; Agirre, X.; Hernández-Rivas, J.M.; Lumbreras, E.; Buño, I.; Martinez-Laperche, C.; et al. Correlation of Myelodysplastic Syndromes with i(17)(Q10) and TP53 and SETBP1 Mutations. Br. J. Haematol. 2015, 171, 137-141. [CrossRef]

83. Patnaik, M.M.; Vallapureddy, R.; Yalniz, F.F.; Hanson, C.A.; Ketterling, R.P.; Lasho, T.L.; Finke, C.; Al-Kali, A.; Gangat, N.; Tefferi, A. Therapy Related-Chronic Myelomonocytic Leukemia (CMML): Molecular, Cytogenetic, and Clinical Distinctions from de Novo CMML. Am. J. Hematol 2018, 93, 65-73. [CrossRef]

84. Bejar, R.; Stevenson, K.; Abdel-Wahab, O.; Galili, N.; Nilsson, B.; Garcia-Manero, G.; Kantarjian, H.; Raza, A.; Levine, R.L.; Neuberg, D.; et al. Clinical Effect of Point Mutations in Myelodysplastic Syndromes. N. Engl. J. Med. 2011, 364, 2496-2506. [CrossRef]

85. Bernard, E.; Nannya, Y.; Hasserjian, R.P.; Devlin, S.M.; Tuechler, H.; Medina-Martinez, J.S.; Yoshizato, T.; Shiozawa, Y.; Saiki, R.; Malcovati, L.; et al. Implications of TP53 Allelic State for Genome Stability, Clinical Presentation and Outcomes in Myelodysplastic Syndromes. Nat. Med. 2020, 26, 1549-1556. [CrossRef]

86. Shih, L.-Y.; Lin, T.-L.; Wang, P.-N.; Wu, J.-H.; Dunn, P.; Kuo, M.-C.; Huang, C.-F. Internal Tandem Duplication of Fms-like Tyrosine Kinase 3 Is Associated with Poor Outcome in Patients with Myelodysplastic Syndrome. Cancer 2004, 101, 989-998. [CrossRef]

87. Vallapureddy, R.; Lasho, T.L.; Hoversten, K.; Finke, C.M.; Ketterling, R.; Hanson, C.; Gangat, N.; Tefferi, A.; Patnaik, M.M. Nucleophosmin 1 (NPM1) Mutations in Chronic Myelomonocytic Leukemia and Their Prognostic Relevance. Am. J. Hematol. 2017, 92, E614-E618. [CrossRef] 
88. Merlevede, J.; Droin, N.; Qin, T.; Meldi, K.; Yoshida, K.; Morabito, M.; Chautard, E.; Auboeuf, D.; Fenaux, P.; Braun, T.; et al. Mutation Allele Burden Remains Unchanged in Chronic Myelomonocytic Leukaemia Responding to Hypomethylating Agents. Nat. Commun. 2016, 7, 10767. [CrossRef]

89. Gotlib, J.; Maxson, J.E.; George, T.I.; Tyner, J.W. The New Genetics of Chronic Neutrophilic Leukemia and Atypical CML: Implications for Diagnosis and Treatment. Blood 2013, 122, 1707-1711. [CrossRef]

90. Crisà, E.; Nicolosi, M.; Ferri, V.; Favini, C.; Gaidano, G.; Patriarca, A. Atypical Chronic Myeloid Leukemia: Where Are We Now? Int. J. Mol. Sci. 2020, 21, 6862. [CrossRef]

91. Patnaik, M.M.; Lasho, T.L.; Finke, C.M.; Hanson, C.A.; King, R.L.; Ketterling, R.P.; Gangat, N.; Tefferi, A. Vascular Events and Risk Factors for Thrombosis in Refractory Anemia with Ring Sideroblasts and Thrombocytosis. Leukemia 2016, 30, 2273-2275. [CrossRef]

92. Calvo, X.; Garcia-Gisbert, N.; Parraga, I.; Gibert, J.; Florensa, L.; Andrade-Campos, M.; Merchan, B.; Garcia-Avila, S.; Montesdeoca, S.; Fernández-Rodríguez, C.; et al. Oligomonocytic and Overt Chronic Myelomonocytic Leukemia Show Similar Clinical, Genomic, and Immunophenotypic Features. Blood Adv. 2020, 4, 5285-5296. [CrossRef]

93. Flex, E.; Jaiswal, M.; Pantaleoni, F.; Martinelli, S.; Strullu, M.; Fansa, E.K.; Caye, A.; De Luca, A.; Lepri, F.; Dvorsky, R.; et al. Activating Mutations in RRAS Underlie a Phenotype within the RASopathy Spectrum and Contribute to Leukaemogenesis. Hum. Mol. Genet. 2014, 23, 4315-4327. [CrossRef]

94. Niemeyer, C.M. JMML Genomics and Decisions. Hematology 2018, 2018, 307-312. [CrossRef]

95. Stieglitz, E.; Taylor-Weiner, A.N.; Chang, T.Y.; Gelston, L.C.; Wang, Y.-D.; Mazor, T.; Esquivel, E.; Yu, A.; Seepo, S.; Olsen, S.R.; et al. The Genomic Landscape of Juvenile Myelomonocytic Leukemia. Nat. Genet. 2015, 47, 1326-1333. [CrossRef]

96. Sugimoto, Y.; Muramatsu, H.; Makishima, H.; Prince, C.; Jankowska, A.M.; Yoshida, N.; Xu, Y.; Nishio, N.; Hama, A.; Yagasaki, H.; et al. Spectrum of Molecular Defects in Juvenile Myelomonocytic Leukaemia Includes ASXL1 Mutations. Br. J. Haematol. 2010, 150, 83-87. [CrossRef]

97. Caye, A.; Strullu, M.; Guidez, F.; Cassinat, B.; Gazal, S.; Fenneteau, O.; Lainey, E.; Nouri, K.; Nakhaei-Rad, S.; Dvorsky, R.; et al. Juvenile Myelomonocytic Leukemia Displays Mutations in Components of the RAS Pathway and the PRC2 Network. Nat. Genet. 2015, 47, 1334-1340. [CrossRef]

98. Bresolin, S.; De Filippi, P.; Vendemini, F.; D'Alia, M.; Zecca, M.; Meyer, L.H.; Danesino, C.; Locatelli, F.; Masetti, R.; Basso, G.; et al. Mutations of SETBP1 and JAK3 in Juvenile Myelomonocytic Leukemia: A Report from the Italian AIEOP Study Group. Oncotarget 2016, 7, 28914-28919. [CrossRef]

99. Stieglitz, E.; Troup, C.B.; Gelston, L.C.; Haliburton, J.; Chow, E.D.; Yu, K.B.; Akutagawa, J.; Taylor-Weiner, A.N.; Liu, Y.L.; Wang, Y.-D.; et al. Subclonal Mutations in SETBP1 Confer a Poor Prognosis in Juvenile Myelomonocytic Leukemia. Blood 2015, 125, 516-524. [CrossRef]

100. Stieglitz, E.; Mazor, T.; Olshen, A.B.; Geng, H.; Gelston, L.C.; Akutagawa, J.; Lipka, D.B.; Plass, C.; Flotho, C.; Chehab, F.F.; et al. Genome-Wide DNA Methylation Is Predictive of Outcome in Juvenile Myelomonocytic Leukemia. Nat. Commun. 2017, 8, 2127. [CrossRef]

101. Fu, Y.; Schroeder, T.; Zabelina, T.; Badbaran, A.; Bacher, U.; Kobbe, G.; Ayuk, F.; Wolschke, C.; Schnittger, S.; Kohlmann, A.; et al. Postallogeneic Monitoring with Molecular Markers Detected by Pretransplant Next-Generation or Sanger Sequencing Predicts Clinical Relapse in Patients with Myelodysplastic/Myeloproliferative Neoplasms. Eur. J. Haematol. 2014, 92, 189-194. [CrossRef]

102. Carbonell, D.; Suárez-González, J.; Chicano, M.; Andrés-Zayas, C.; Triviño, J.C.; Rodríguez-Macías, G.; Bastos-Oreiro, M.; Font, P.; Ballesteros, M.; Muñiz, P.; et al. Next-Generation Sequencing Improves Diagnosis, Prognosis and Clinical Management of Myeloid Neoplasms. Cancers 2019, 11, 1364. [CrossRef]

103. Vantyghem, S.; Peterlin, P.; Thépot, S.; Ménard, A.; Dubruille, V.; Debord, C.; Guillaume, T.; Garnier, A.; Bourgeois, A.L.; Wuilleme, S.; et al. Diagnosis and prognosis are supported by integrated assessment of next-generation sequencing in chronic myeloid malignancies. A real-life study. Haematologica 2021, 106, 701-707. [CrossRef] [PubMed]

104. Nagata, Y.; Zhao, R.; Awada, H.; Kerr, C.M.; Mirzaev, I.; Kongkiatkamon, S.; Nazha, A.; Makishima, H.; Radivoyevitch, T.; Scott, J.G.; et al. Machine Learning Demonstrates That Somatic Mutations Imprint Invariant Morphologic Features in Myelodysplastic Syndromes. Blood 2020, 136, 2249-2262. [CrossRef] [PubMed]

105. Haferlach, T. Human and Artificial Intelligence to Illuminate MDS. Blood 2020, 136, 2243-2244. [CrossRef] [PubMed]

106. Walter, W.; Pfarr, N.; Meggendorfer, M.; Jost, P.; Haferlach, T.; Weichert, W. Next-generation diagnostics for precision oncology: Preanalytical considerations, technical challenges, and available technologies. Semin. Cancer Biol. 2020. [CrossRef]

107. Pophali, P.; Matin, A.; Mangaonkar, A.A.; Carr, R.; Binder, M.; Al-Kali, A.; Begna, K.H.; Reichard, K.K.; Alkhateeb, H.; Shah, M.V.; et al. Prognostic impact and timing considerations for allogeneic hematopoietic stem cell transplantation in chronic myelomonocytic leukemia. Blood Cancer J. 2020, 10, 121. [CrossRef]

108. Thota, S.; Gerds, A.T. Myelodysplastic and myeloproliferative neoplasms: Updates on the overlap syndromes. Leuk. Lymphoma 2018, 59, 803-812. [CrossRef] 